\title{
First in-depth analysis of the novel Th2-type cytokines in salmonid fish reveals distinct patterns of expression and modulation but overlapping bioactivities
}

\author{
Tiehui Wang ${ }^{1}$, Petronella Johansson ${ }^{1}$, Beatriz Abós ${ }^{2}$, Amy Holt ${ }^{1}$, Carolina Tafalla ${ }^{2}$, \\ Youshen Jiang ${ }^{1,3}$, Alex Wang ${ }^{1}$, Qiaoqing $X \mathbf{u}^{1,4}$, Zhitao $\mathbf{Q}^{i^{1,5}}$, Wenshu Huang ${ }^{1,6}$, \\ Maria M. Costa ${ }^{1,7}$, Patricia Diaz-Rosales ${ }^{1}$, Jason W. Holland ${ }^{1}$ and Christopher J. \\ Secombes ${ }^{1}$ \\ ${ }^{1}$ Scottish Fish Immunology Research Centre, School of Biological Sciences, University of Aberdeen, Aberdeen, UK \\ ${ }^{2}$ Centro de Investigación en Sanidad Animal (CISA-INIA), Valdeolmos (Madrid), Spain \\ ${ }^{3}$ College of Fishery and Life Science, Shanghai Ocean University, Shanghai, China \\ ${ }^{4}$ School of Animal Science, Yangtze University, Jingzhou, Hubei Province, China \\ ${ }^{5}$ Central Laboratory of Biology, Chemical and Biological Engineering College, Yancheng Institute of Technology, Yancheng, \\ Jiangsu Province, China \\ ${ }^{6}$ Fisheries College, Jimei University, Xiamen, Fujian Province, China \\ ${ }^{7}$ Instituto de Investigaciones Marinas, Consejo Superior de Investigaciones Científicas (CSIC), Vigo, Spain \\ Correspondence to: Tiehui Wang, email: t.h.wang@abdn.ac.uk
}

Christopher J Secombes, email: c.secombes@abdn.ac.uk

Keywords: rainbow trout Oncorhynchus mykiss, IL-4/13A and 13B, expression, bioactivity, type-2 immunity, Immunology and Microbiology Section, Immune response, Immunity

Received: October 12, $2015 \quad$ Accepted: January 24, $2016 \quad$ Published: February 09, 2016

\section{ABSTRACT}

IL-4 and IL-13 are closely related canonical type- 2 cytokines in mammals and have overlapping bioactivities via shared receptors. They are frequently activated together as part of the same immune response and are the signature cytokines produced by T-helper (Th) 2 cells and type-2 innate lymphoid cells (ILC2), mediating immunity against extracellular pathogens. Little is known about the origin of type2 responses, and whether they were an essential component of the early adaptive immune system that gave a fitness advantage by limiting collateral damage caused by metazoan parasites. Two evolutionary related type- 2 cytokines, IL-4/13A and IL-4/13B, have been identified recently in several teleost fish that likely arose by duplication of an ancestral IL-4/13 gene as a consequence of a whole genome duplication event that occurred at the base of this lineage. However, studies of their comparative expression levels are largely missing and bioactivity analysis has been limited to IL-4/13A in zebrafish. Through interrogation of the recently released salmonid genomes, species in which an additional whole genome duplication event has occurred, four genomic IL-4/13 loci have been identified leading to the cloning of three active genes, IL-4/13A, IL-4/13B1 and IL-4/13B2, in both rainbow trout and Atlantic salmon. Comparative expression analysis by real-time PCR in rainbow trout revealed that the IL-4/13A expression is broad and high constitutively but less responsive to pathogen-associated molecular patterns (PAMPs) and pathogen challenge. In contrast, the expression of IL-4/13B1 and IL-4/13B2 is low constitutively but is highly induced by viral haemorrhagic septicaemia virus (VHSH) infection and during proliferative kidney disease (PKD) in vivo, and by formalin-killed bacteria, PAMPs, the T cell mitogen PHA, and the T-cell cytokines IL-2 and IL-21 in vitro. Moreover, bioactive recombinant cytokines of both IL-4/13A and $B$ were 
produced and found to have shared but also distinct bioactivities. Both cytokines rapidly induce the gene expression of antimicrobial peptides and acute phase proteins, providing an effector mechanism of fish type-2 cytokines in immunity. They are anti-inflammatory via up-regulation of IL-10 and down-regulation of IL-1 $\beta$ and IFN-Y. They modulate the expression of cellular markers of T cells, macrophages and B cells, the receptors of IFN-Y, the IL-6 cytokine family and their own potential receptors, suggesting multiple target cells and important roles of fish type-2 cytokines in the piscine cytokine network. Furthermore both cytokines increased the number of IgM secreting $B$ cells but had no effects on the proliferation of IgM+ B cells in vitro. Taken as a whole, fish IL-4/13A may provide a basal level of type-2 immunity whilst IL-4/13B, when activated, provides an enhanced type-2 immunity, which may have an important role in specific cell-mediated immunity. To our knowledge this is the first in-depth analysis of the expression, modulation and bioactivities of type-2 cytokines in the same fish species, and in any early vertebrate. It contributes to a broader understanding of the evolution of type- 2 immunity in vertebrates, and establishes a framework for further studies and manipulation of type-2 cytokines in fish.

\section{INTRODUCTION}

Mammalian interleukin (IL)-4 and IL-13 were among the first cytokines described in the early 1980s [1-2]. IL-4 was initially identified as a $\mathrm{T}$ cell-derived B cell growth factor [3] and an immunoglobulin (Ig) switch factor for IgG1 [4] and IgE [5], and was later found to act also on T cells, mast cells [6], macrophages, cells of the myeloid and erythroid lineages, and nonhemopoietic cells [7]. In 1989, IL-13, a close congener of IL-4, was found to mediate virtually all of the IL-4 actions on non-haematopoietic cells and to some degree on haematopoietic cells [8]. Although they share low amino acid sequence identity, eg $23 \%$ in humans and $22 \%$ in cow, IL-4 and IL-13 are indeed closely related. They sit side by side in the mammalian genome and form part of a contiguous gene cluster sharing regulatory elements, and are frequently activated together as part of the same immune response [1,9-10]. They function not only in the immune system but also in pregnancy, fetal development, mammary development and lactation, and in higher brain functions including memory and learning in mammals [11].

In the mammalian immune system, IL-4 and IL-13 are type- 2 cytokines that drive canonical type- 2 immunity, characterised by eosinophilia, mast cell hyperplasia, IgE secretion, smooth muscle contraction and epithelial remodelling [1, 9, 12-13]. These responses offer protection against helminth parasites but can also be damaging when activated inappropriately, leading to type- 2 inflammatory conditions such as allergy and asthma [13-15]. IL-4 and IL-13 are produced by CD4 ${ }^{+}$T-helper type 2 (Th2) cells, effecting host immunity against extracellular parasites. The canonical type- 2 cytokine-induced responses are mediated via STAT (Signal Transducer and Activator of Transcription)6/GATA3. The binding of IL-4 or IL-13 to their receptors results in the phosphorylation of STAT6, which dimerizes, translocates to the nucleus and induces GATA3 expression. This signaling pathway creates a positive feedback loop to maintain IL-4 and IL-13 production in Th2 cells. Thus, GATA3 promotes type2 cytokine expression, and additionally auto-activates its own transcription thereby stabilizing the Th2 fate [16]. IL-4 and IL-13 production in Th cells can also be potentiated by non-canonical pathways, as seen with IL-2 that can drive IL-4 transcription in an IL-4R-independent manner through the phosphorylation of STAT5 [17].

In addition to production of IL-4 and IL-13 by mammalian Th2 cells, innate immune cells (eg basophils, eosinophils and mast cells) constitutively express both molecules and represent important sources of type-2 cytokines early during type-2 immunity [18-20]. These cells can rapidly release cytokines within 5-10 min, due to the presence of pre-formed type-2 cytokines in their secretory granules, and can also generate cytokines de novo following stimulation [21]. Furthermore, invariant Natural Killer T cells, a population of innate $T$ lymphocytes, and type-2 innate lymphoid cells (ILC2) are also implicated as a major source of IL-4 and IL-13 production in vivo [22-23].

IL-4 and IL-13 signal through cell surface heterodimeric receptors composed of 3 possible subunits, IL-4R $\alpha$, IL-13R $\alpha 1$ and the common- $\gamma$ chain $(\gamma \mathrm{C})$. IL-4 signals through both the type I receptor composed of the IL-4R $\alpha$ and $\gamma \mathrm{C}$, and the type II receptor composed of the IL-4R $\alpha$ and IL-13R $\alpha$ 1, whilst IL-13 only signals through the type II receptor $[1,9]$. IL-4 binds IL-4R $\alpha$ with very high affinity $(\mathrm{KD}=20-300 \mathrm{pM})$, leading to the recruitment of either $\gamma \mathrm{C}$ or IL-13R $\alpha 1$, that both have lower, approximately equal affinity for the IL-4:IL-4R $\alpha$ complex $(\mathrm{KD}=500 \mathrm{nM})$. Binding of IL-4 to the type I receptor complex activates JAK $1 / 3$. In contrast, IL-13 binds to IL$13 \mathrm{R} \alpha 1$ with moderate affinity $(\mathrm{KD}=30 \mathrm{nM})$ relative to the IL-4:IL-4R $\alpha$ interaction, leading to recruitment of the IL-4R $\alpha$ subunit and activation of JAK1 or JAK2/TYK2. IL-13 can also bind with extraordinarily high affinity [ < $10^{-15} \mathrm{M}$,] to IL-13R $\alpha 2$, which is believed to be a "decoy" receptor for IL-13 owing to its lack of a cytoplasmic tail 
and signaling motifs [24]. The IL-4 and IL-13 receptor subunits are expressed at low levels under normal homeostatic conditions, but are influenced by hormones, cellular/oxidative stress, infection and inflammation [25]. Whilst the IL-4R $\alpha$ and IL-13R $\alpha 1$ chains are widely expressed at low levels on most cell types, the $\gamma \mathrm{C}$ chain is primarily expressed on hematopoietic immune cells [9]. Therefore, the availability of each receptor subunit on the cell surface, and concentration of IL-4 vs. IL-13 in the extracellular milieu are important determinants of the signaling pathway activated within the responding cells [1, 9]. IL-4 and IL-13 can elicit overlapping but also unique biological responses. For example, in the pathogenesis of allergic asthma, IL-4 and IL-13 play an important role in tandem, with IL-4 having a pivotal role in Th2 cell proliferation, cytokine production and IgE synthesis, whilst IL-13 plays a pivotal role in the effector phase of the disease [14].

Little is known about the origin of type- 2 responses, and whether they were an essential component of the early adaptive immune system that gave a fitness advantage by limiting collateral damage caused by metazoan parasites. In addition, whilst Th2 responses have been known for a long time [2] there are still many questions relating to the mechanisms that initiate and control these responses in mammals [26], which comparative studies in other vertebrates may aid. All the receptor subunits of IL-4 and IL-13 (IL-4R $\alpha, \gamma \mathrm{C}$, IL-13R $\alpha 1$ and IL-13R $\alpha 2$ ) exist throughout the jawed vertebrates [10], with two copies of each present in salmonids [27-29]. IL-4 and IL-13 are present in mammals and birds but clear orthologues of IL-4 or IL-13 are missing in other vertebrates [10]. The first IL-4/IL-13 related gene was identified adjacent to RAD50 in the pufferfish (Tetraodon nigroviridis) genome by Li and colleagues [30]. A second IL-4/IL-13 like gene was discovered in zebrafish (Danio rerio) at a different locus (adjacent to KIF3A) [31]. Subsequent analysis of the two loci has revealed that they most likely arose as a consequence of the third round (3R) whole genome duplication (WGD) event that happened in the teleost fish ancestor. Hence, the two genes were called IL-4/13A (adjacent to RAD50) and IL-4/13B (adjacent to KIF3A) [32]. More recently a single IL-4/13 gene was identified in the genome of the $2 \mathrm{R}$ bony fish, spotted gar (Lepisosteus oculatus) between KIF3A and RAD50 [10], and at least two IL-4/13 genes have been found between KIF3A and RAD50 in the elephant shark (Callorhinchus milii), a 2R cartilaginous fish [33-34]. It seems likely that a single IL-4/IL-13 gene existed in ancestral Gnathostomes, which has been duplicated in different lineages by WGD and/or tandem duplication events [10].

To date, functional analysis of IL-4/13A and IL-4/13B in fish is limited. The tetraodon IL-4/13A exhibits constitutive expression in most tissues studied, being higher in gills, brain, muscle and heart [30]. High constitutive expression of IL-4/13A has been found in salmonid mucosal tissues (gill, skin) [35]. In addition, IL4/13A has been found to be up-regulated in rainbow trout Oncorhynchus mykiss epidermis 9 days post-infection with Ichthyobodo necator compared with uninfected fish [36]. Interestingly, a cell line (KoThL5) that expresses IL4/13B has been established from carp (Cyprinus carpio) [37]. These cells also express TCR chains, and a CD4like molecule (termed CD4-1), a phenotype similar to mammalian Th2 cells. Bioactivity analysis has only been carried out using recombinant zebrafish IL-4/13A [38-39]. Administration of IL-4/13A in vivo increased the numbers of peripheral blood leucocytes that express the IgZ-2 isoform after two days, or DC-SIGN after 5 days [38], and significantly upregulated B cell proliferation and antibody production [39]. The bioactivity of IL-4/13B is unknown in any fish species, and the comparative expression and modulation of both IL-4/13A and B paralogues in the same species is currently lacking.

In this study, we first identified four IL-4/13 genomic loci in the salmonid genome, that enabled the cloning of three active genes, IL-4/13A, B1 and B2. Comparative transcriptional analysis was undertaken in tissues from healthy fish, in cell lines and purified immune cells, and during parasitic, viral and bacterial infections. Bioactive recombinant proteins were generated for all the three trout IL-4/13 isoforms. Functional analysis revealed overlapping yet distinct functionalities in terms of transcriptional modulation of other immune genes and their impact on B cell populations.

\section{RESULTS}

\section{Salmonids possess three active fish-specific Th2 cytokines, IL-4/13A, IL-4/13B1 and IL-4/13B2, and an IL-4/13A pseudogene}

Three IL-4/13 cDNA sequences with complete coding sequence (CDS) have been cloned in both rainbow trout and Atlantic salmon Salmo salar that match genomic sequences in the database (Supplementary Figures S1-S2 and 4-7, and Table 1). According to homology and linkage to RAD50 and KIF3A [1, 32] (Figure 1 and Table 1), they have been named as IL-4/13A, IL-4/13B1 and IL-4/13B2, with the likelihood that the last two genes have originated from the salmonid 4R WGD event [40]. Each gene has a potential polyadenylation signal and between 2 and 4 ATTTA motifs in the 3'-untranlated region (UTR). An in frame stop codon is also apparent in the 5'-UTR in all the genes, except salmon IL-4/13B2 (Figures S1-S2 and 4-7, and Table 1).

A Whole Genome Shotgun (WGS) sequence contig (Acc. no. AGKD03032511) was also identified in Atlantic salmon that had a putative exon corresponding to the last exon of the IL-4/13A gene (designated as IL-4/13p). 
This exon, when translated, has $48.7 \%$ identity to the last exon of salmon IL-4/13A and $61.5 \%$ identity to that of trout IL-4/13A, and has a potential polyadenylation signal (Figure S3). However, a canonical intron acceptor site (AG) is missing at the intron junction and ATTTA motifs are missing in the putative 3'-UTR that are present in the 3 '-UTR of all the other salmonid IL-4/13 genes.
No other IL-4/13 exons could be identified upstream of this last exon. Furthermore, this putative exon sits in a syntenically conserved locus, with the salmonid IL-4/13A gene downstream of genes including POU4F3, RBM27 and LARS (Figure 1). Such evidence suggests it originated from a decayed IL-4/13A gene after the salmonid 4R WGD event [40].

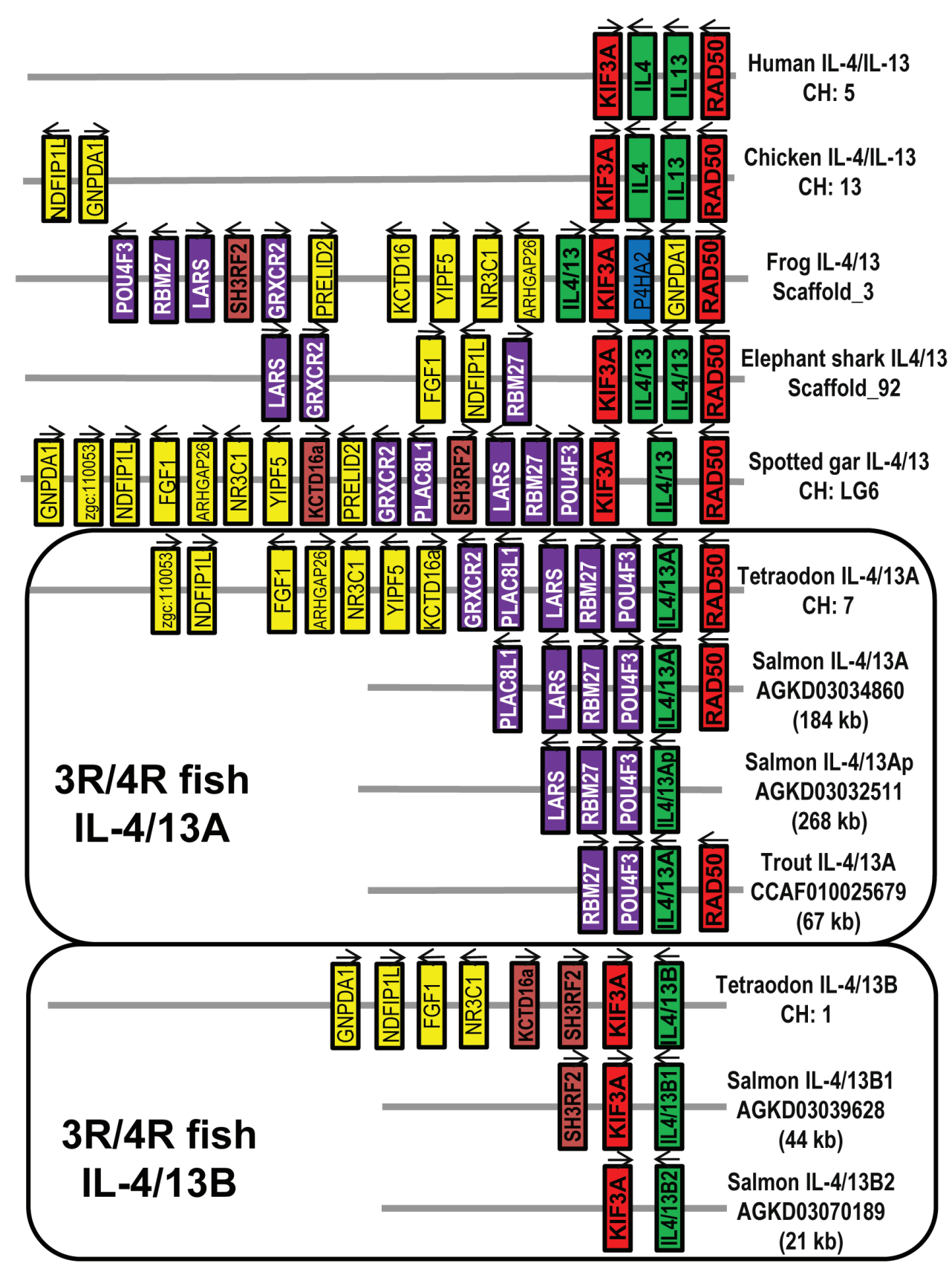

Figure 1: Gene synteny at the Th2 loci across vertebrates. The KIF3A/IL-4/IL-13/RAD50 loci were analysed using the Genomicus program (genomicus, database release-78.01). The information for frog and elephant shark is extracted from NCBI genomic sequence NW_004668234 (frog Xenopus (Silurana) tropicalis) and NW_006890145 (shark Callorhinchus milii). The spotted gar locus was used as a reference with conserved genes colour-matched. The salmonid IL-4/13 loci were derived from the WGS contigs of Atlantic salmon and rainbow trout (Table 1). 
Table 1: Summary of sequence analysis of salmonid IL-4/13 genes

\begin{tabular}{|c|c|c|c|c|c|c|c|}
\hline & Features & $\begin{array}{l}\text { Trout } \\
\text { IL-4/13A } \\
\end{array}$ & $\begin{array}{l}\text { Salmon } \\
\text { IL-4/13A }\end{array}$ & $\begin{array}{l}\text { Trout } \\
\text { |L-4/13B1 } \\
\end{array}$ & $\begin{array}{l}\text { Salmon } \\
\text { IL-4/13B1 }\end{array}$ & $\begin{array}{l}\text { Trout } \\
\text { |L-4/13B2 }\end{array}$ & $\begin{array}{l}\text { Salmon } \\
\text { IL-4/13B2 }\end{array}$ \\
\hline \multirow[t]{6}{*}{ cDNA } & Accession number & FN820500 & AB574339a & HG794522 & HG794524 & HG794523 & HG794525 \\
\hline & Length (bp) & 794 & 455 & 548 & 696 & 565 & 683 \\
\hline & $\begin{array}{l}\text { In frame stop codon in } \\
\text { 5'UTR }\end{array}$ & Yes & Yes & Yes & Yes & Yes & No \\
\hline & ORF (bp) & 438 & 429 & 453 & 453 & 462 & 444 \\
\hline & PolyA signal & Yes & Yes & Yes & Yes & Yes & Yes \\
\hline & ATTTA motifs & 2 & 2 & 3 & 4 & 3 & 3 \\
\hline $\begin{array}{l}\text { Genomic } \\
\text { DNA }\end{array}$ & Accession number & FN820501 & $\begin{array}{c}\text { AGKD0108305 } \\
7\end{array}$ & $\begin{array}{c}\text { CCAF0101440 } \\
13\end{array}$ & $\begin{array}{c}\text { AGKD0303962 } \\
8\end{array}$ & $\begin{array}{c}\text { CCAF0100961 } \\
58\end{array}$ & $\begin{array}{c}\text { AGKD0400108 } \\
9\end{array}$ \\
\hline \multirow[t]{7}{*}{ Protein } & Full length (aa) & 145 & 142 & 150 & 150 & 153 & 147 \\
\hline & Signal peptide (aa) & 24 & 23 & 17 & 17 & 17 & 17 \\
\hline & Mature peptide (aa) & 121 & 119 & 133 & 133 & 136 & 130 \\
\hline & Cysteine residues & 4 & 4 & 4 & 4 & 6 & 6 \\
\hline & $\mathrm{pl}^{\mathrm{b}}$ & 7.20 & 8.72 & 7.90 & 6.72 & 7.82 & 4.91 \\
\hline & MWc & 13.70 & 13.69 & 15.06 & 15.16 & 15.33 & 14.46 \\
\hline & $\mathrm{N}$-glycosylation sites ${ }^{\mathrm{d}}$ & 0 & 2 & 3 & 2 & 1 & 2 \\
\hline \multirow{6}{*}{$\begin{array}{l}\text { Full- } \\
\text { length aa } \\
\text { identity } \\
\text { (top right) } \\
\text { /similarity } \\
\text { (bottom } \\
\text { left)e }\end{array}$} & Trout IL-4/13A & & $81.5^{\mathrm{e}}$ & 29.3 & 28.7 & 26.3 & 28.5 \\
\hline & Salmon IL-4/13A & 89.0 & & 27.6 & 28.0 & 26.8 & 27.1 \\
\hline & Trout IL-4/13B1 & 44.7 & 43.3 & & $82.0 e$ & 66.0 & 65.1 \\
\hline & Salmon IL-4/13B1 & 46.0 & 46.0 & 88.0 & & 62.7 & 61.8 \\
\hline & Trout IL-4/13B2 & 43.8 & 42.5 & 75.8 & 72.5 & & $82.4^{\mathrm{e}}$ \\
\hline & Salmon IL-4/13B2 & 46.9 & 46.3 & 74.7 & 72.7 & 86.3 & \\
\hline
\end{tabular}

Note:

a. Salmon IL-4/13A cDNA was retrieved from the database.

b. $\mathrm{pI}$ of predicted mature peptides.

c. Theoretical molecular weight $(\mathrm{kDa})$ of the predicted mature peptides.

d. Potential N-glycosylation sites.

e. The identities of salmonid orthologues of IL-4/13A, B1 and B2 are in bold.

The salmonid IL-4/13 genes encode proteins of 142153 aa, with predicted signal peptides of 17-24 aa, mature peptides of 119-136 aa, and 0-3 potential N-glycosylation sites (Figures S1-S2, S4-S7; Table 1). The mature peptides of salmonid IL-4/13 isoforms have theoretical molecular weights of $13.69-15.33 \mathrm{kDa}$. All trout IL-4/13 isoforms have a basic pI (7.20-7.90). Salmon IL-4/13A is also basic $(\mathrm{pI}=8.72)$, but the two salmon IL-4/13B isoforms are acidic ( $\mathrm{pI}=6.72$ for $\mathrm{B} 1$ and 4.91 for B2) (Table 1). The salmonid IL-4/13 isoforms have four conserved cysteine residues with two additional cysteine residues at the C-terminal of salmonid IL-4/13B2 (Figure S8). The aa identities of the trout and salmon molecules are highest (81.5-82.4\%) between the orthologues of salmonid IL-4/13 isoforms from the 4R WGD (isoforms A, B1 or B2), although this is relatively low compared to other cytokines. Moderate identity (61.8-66.0\%) is seen between the paralogues from the 4R WGD (between B1 and B2) and only low identity (26.3-29.3\%) is seen between the paralogues from the 3R WGD (between A and B, Table 1).

\section{Sequence analysis reveals lineage-specific evolution}

Amino acid identity/similarity analysis between fish IL-4/13 molecules, tetrapod IL-4 and IL-13, and other $\gamma$-chain cytokines revealed the salmonid IL-4/13A and B isoforms to have similar identities/similarities to other IL-4/IL-13 molecules from different lineages (Table S1). Salmonid IL-4/13 isoforms share relatively low identity (24-25\%) to the predicted IL-4/13 from the spotted gar (a $2 \mathrm{R}$ bony fish) and the IL-4/13 molecules from (3R) cyprinids and percomorphs. Even lower identities were seen compared to homeotherm IL-4 and IL-13 (18-21\%), and to other mammalian $\gamma$-chain cytokines $(17-20 \%)$ (Table S1).

To see whether the salmonid molecules allow a greater insight into IL-4/13 evolution, a neighbourjoining phylogenetic tree was constructed based on a multiple alignment of fish IL-4/13, tetrapod IL-4 and IL-13, and other closely related $\gamma$-chain cytokines (IL2, IL-9 and IL-21) (Figure S9). The salmonid IL-4/13 molecules, along with the IL-4/13 molecules from other vertebrates, and tetrapod IL-4 and IL-13 formed a large cluster with $94 \%$ bootstrap support, which was separated from other closely related $\gamma$-chain cytokines, suggesting 
that all the IL-4/13 genes are indeed related to tetrapod IL-4 and IL-13 as suggested by the synteny analysis (Figure 1). Lineage-specific groups, eg IL-4 and IL-13 from mammals and birds, and IL-4/13A and IL-4/13B from salmonids, cyprinids and percomorphs, are well supported. However, fish orthologue-specific groupings, as seen in phylogenetic trees of IL-1 $\beta$ [41], TNF $\alpha$ [42] and the sub-units of IL-12 [43] are missing (Figure S9). The topology of the phylogenetic tree is in agreement with the homology analysis (Table S1) in which aa identities within orthologues (eg IL-4/13A) are no higher than between paralogues (eg IL-4/13A and B), suggesting fast-evolution of the IL-4/13 related genes in vertebrates.

To study further the apparent rapid evolution of the vertebrate IL-4/13 related genes, we analysed their gene organisation. Homeotherm IL-4 and IL-13, the $3 \mathrm{R}$ and $4 \mathrm{R}$ bony fish IL-4/13A and IL-4/13B, and the $2 \mathrm{R}$ vertebrate (shark, gar, amphibian) IL-4/13 genes all have a four coding exon/three phase 0 intron organisation (Figure 2). However, exon 3 appears to be lineage-specific. Exon 3 is larger in tetrapod IL-4 (126-177 bp) than in IL-13 (105$114 \mathrm{bp}$ ), with exon 3 of IL-4/13 genes in $2 \mathrm{R}$ vertebrates

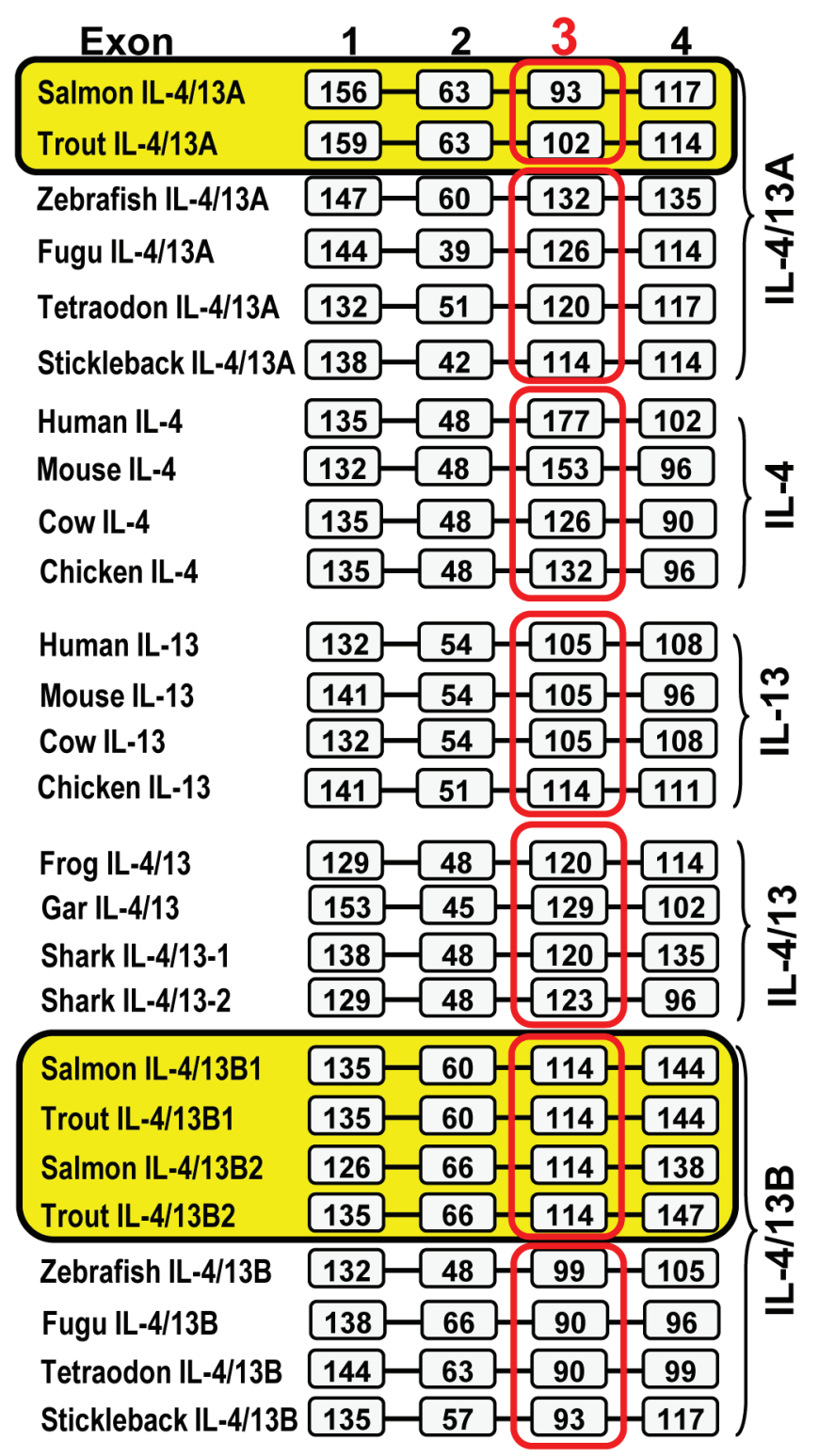

Figure 2: Comparison of the gene organisation of salmonid IL-4/13 genes with IL-4, IL-13 and related genes from other vertebrates. The boxes represent amino acid coding regions and the black bars represent introns. The sizes (bp) of the coding regions are numbered in the boxes. The gene organisation of the salmonid IL-4/13 genes was predicted using the Spidey program based on the sequence information from Tables 1 and Figures S1-S2 and S4-S7. Other genes were extracted from NCBI genomic sequences NW_004668234 (frog IL-4/13) and NW_006890145 (elephant shark IL-4/13-1 and -2) and spotted gar chromosome LG6 (gar IL-4/13). Sequence data representing all other genes was reported by Ohtani et al. [32]. 
A.

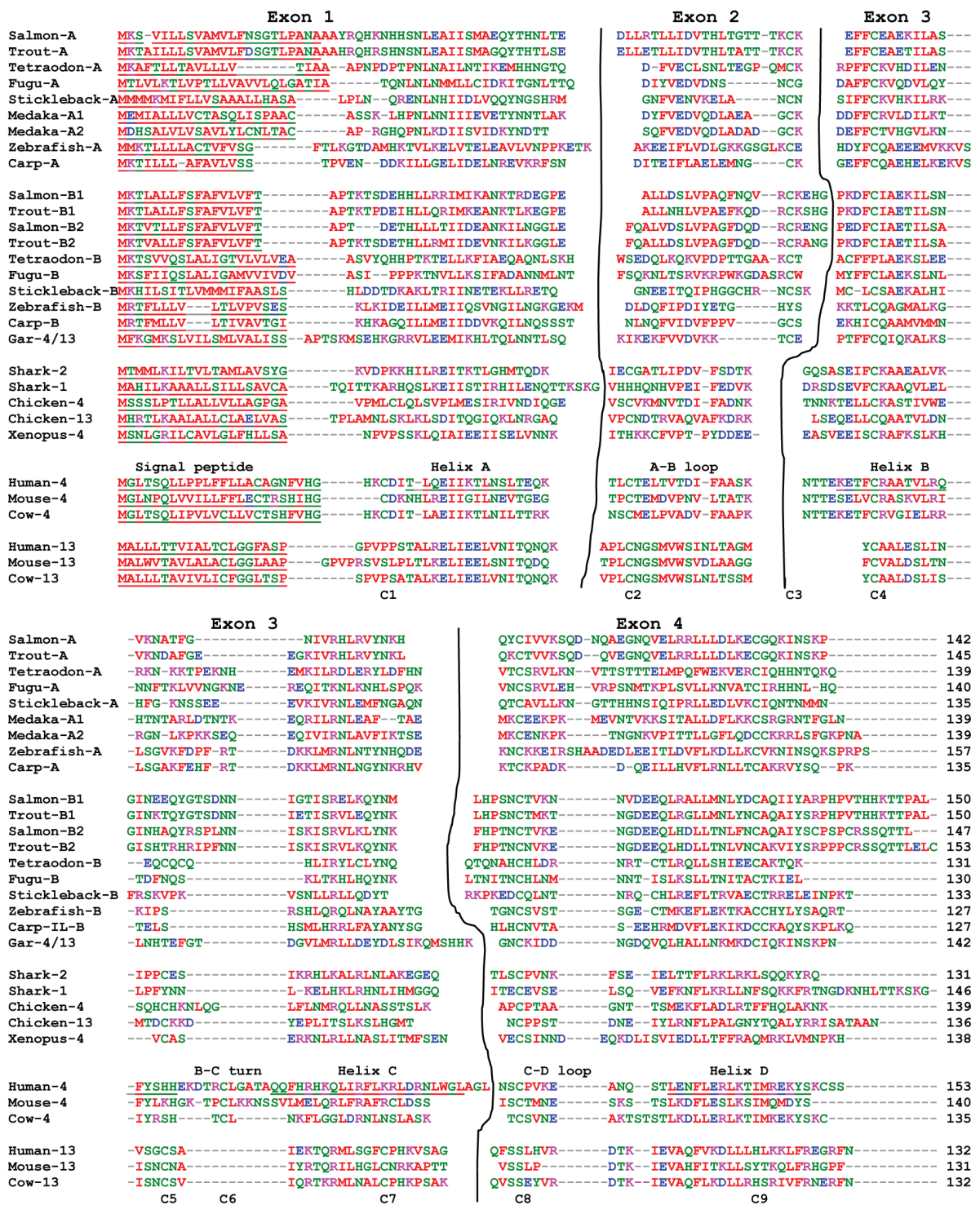

B.

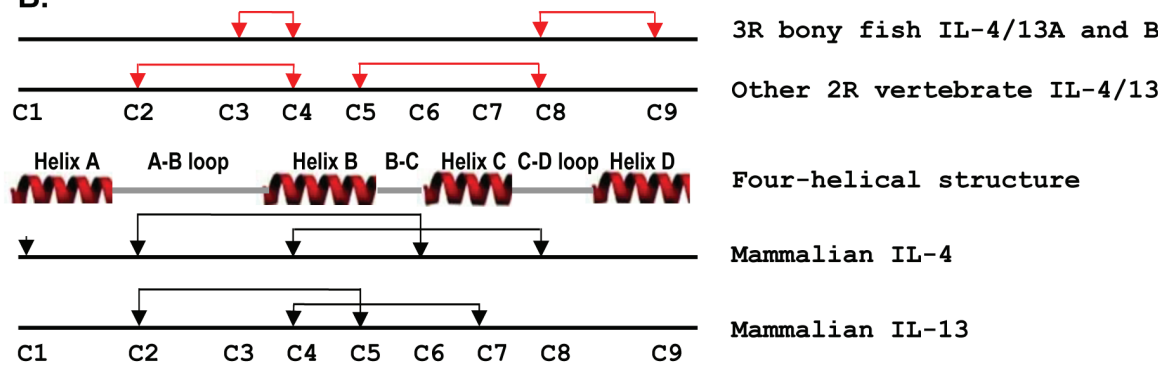

Figure 3: Multiple alignment of mammalian IL-4 and IL-13, and IL-4/13 related molecules from 3R bony fish and other vertebrates $A$ and the patterns of cysteine residues and connectivity prediction in different vertebrate groups. A. The exon-specific multiple alignment was produced using ClustalW. The accession numbers of the amino acid sequences used are as in Figure 2. The four exons are separated and marked above the alignment. The signal peptide, four $\alpha$-helices and loops known in human IL-4 are marked above human IL-4. The nine cysteine residues conserved in different lineages are denoted under the alignment. B. The lineage specific conserved cysteine residues are schematically shown relative to the four helical structure of human IL-4. The known disulfidebonds [47-48] in human IL-4 and IL-13 are shown by black lines and the predicted disulfide bonds [49] are indicated by red-lines. 
being of intermediate size (120-129 bp). Salmonid IL4/13A genes, in contrast to $3 \mathrm{R}$ fish species, possess a smaller exon 3. Exon 3 of human IL-4 encodes for helices $\mathrm{B}$ and $\mathrm{C}$ of the mature peptide, with helix $\mathrm{C}$ having an important role in IL-4 binding to its high affinity receptor chain, IL-4R $\alpha$ [45-46]. Thus, lineage-specific exon 3 may contribute to the lineage specific diversification of IL-4/13 genes and may have had an impact on the functional role of IL-4/13A and IL-4/13B in different lineages/species.

To gain further insights into potential functional diversification of IL-4/13 molecules, a multiple alignment based on exon and secondary structure was generated. In human IL-4 exon 1 encodes for the signal peptide and helix A, whilst exon 2 encodes the A-B loop, exon 3 helices B and $\mathrm{C}$, and the B-C turn, and exon 4 the C-D loop and helix D [46] (Figure 3A). Nine cysteine residues can be identified in the multiple alignment that are conserved in a lineage-specific manner (Figure 3B). Human IL-4 and IL-13 are known to be four-helical cytokines stabilised by two conserved disulfide bonds [47-48]. Predictions of cysteine connectivities using DISULFIND [49] in IL-4/13 molecules from fish and other vertebrates (Figure S10) suggest that lineage/species-specific disulfide bonds may have evolved to stabilise IL-4/13 molecules (Figure 3B).

\section{Comparative transcript expression analysis of the three trout $\mathrm{Th} 2$ cytokines}

The constitutive expression of the three trout Th2 cytokines was comparatively studied in tissues of apparently healthy fish, in cell lines, head kidney (HK) cells, primary $\mathrm{HK}$ macrophages, and purified $\mathrm{IgM}^{+} \mathrm{B}$ cells (Figure 4). The expression of all three isoforms was detectable by real-time RT-PCR in all 17 tissues examined, with the expression of IL-4/13B2 in liver tissue being the lowest. The apparently highest expression of IL-4/13A was found in certain immune tissues/organs (gills, blood and thymus), as well as in tail fins and adipose fin. The apparently highest expression of IL-4/13B1 was also
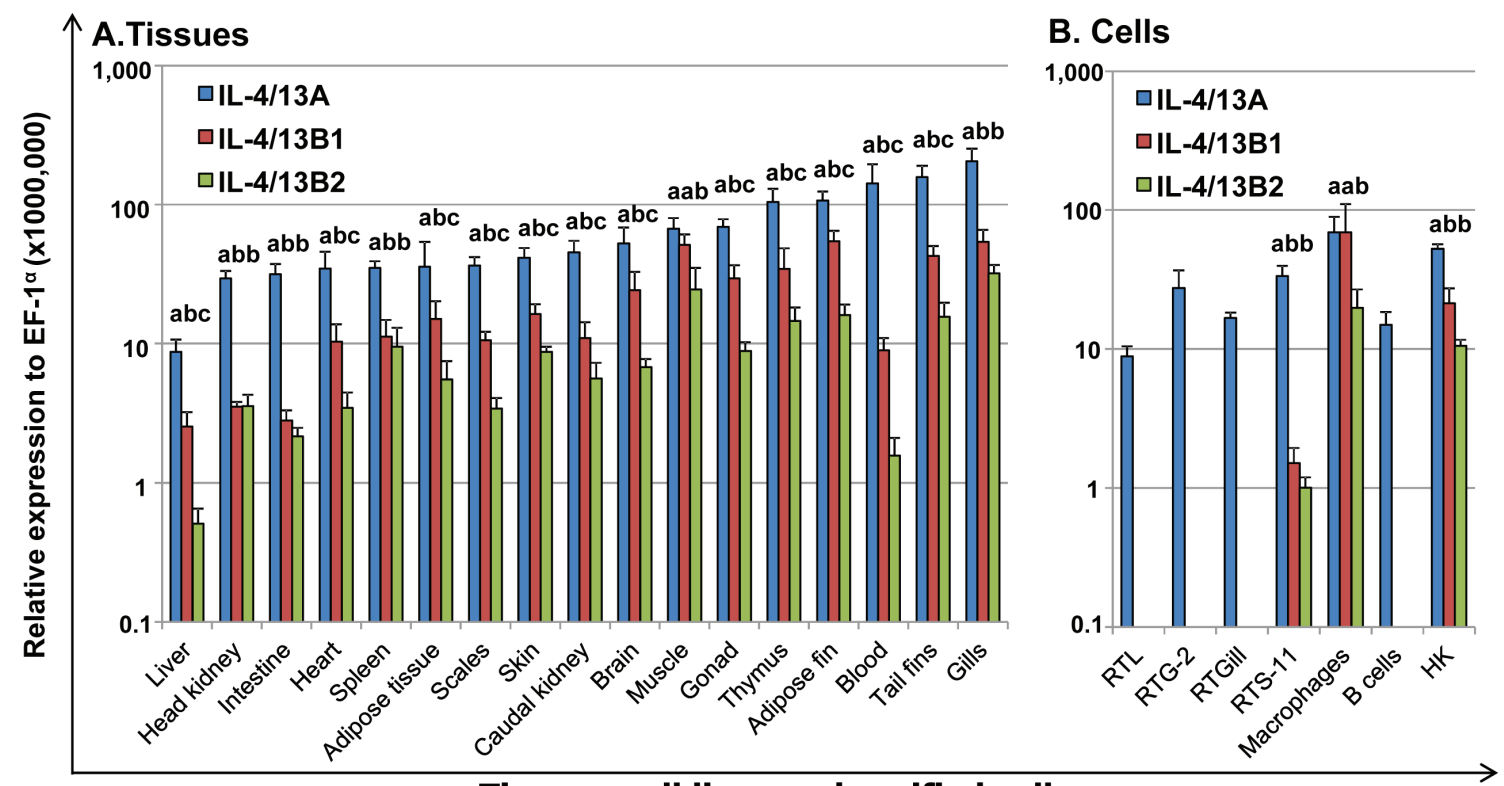

Tissues, cell lines and purified cells

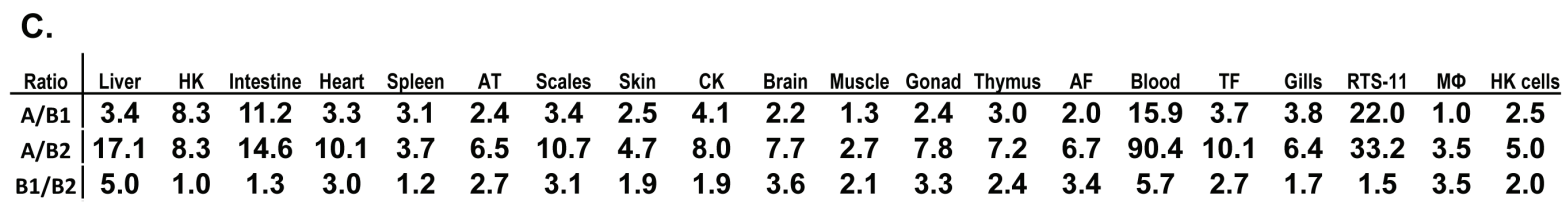

Figure 4: Constitutive expression of trout IL-4/13A, B1 and B2 in vivo in tissues A, in cell lines and purified immune cells $B$ and the ratios of expression levels between each other. A. The transcript expression level of the three trout IL-4/13 paralogues was determined by real time RT-PCR in 17 tissues from six fish. The transcript level was calculated using a serial dilution of references that contained equal molar amounts of the probes for each gene and was normalized against the expression level of EF-1 $\alpha$. The results represent the average + SEM of six fish. B. Total RNA was prepared from cell lines, 4-day old primary HK macrophages, FACS sorted spleen $\operatorname{IgM}^{+} \mathrm{B}$ cells, and $\mathrm{HK}$ cells after $4 \mathrm{~h}$ culture in vitro. The expression analysis was as described in A.. The results represent the average + SEM from four flasks of cells or fish. A paired sample $t$-test was applied to the tissue samples, macrophages and HK cells, and one-way ANOVA was used for the cell lines. The expression levels between IL-4/13A, B1 and B2 in the same tissues or cell lines are significantly different $(p<0.05)$ when the letters over the bars are different. C. The ratio of the expression levels between each of the IL4/13 paralogues. $\mathrm{HK}=$ head kidney, $\mathrm{AT}=$ adipose tissue, $\mathrm{CK}=$ caudal kidney, $\mathrm{AF}=$ adipose fin; $\mathrm{TF}=$ tail fins, $\mathrm{M} \Phi=$ primary macrophages. 
in gills and thymus, as well as in tail fins, adipose fin, muscle, gonad and brain (Figure 4A). The expression of IL-4/13A was significantly higher $(p<0.05)$ than that of IL-4/13B1 and IL-4/13B2 in all tissues except muscle where the expression of IL-4/13A and IL-4/13B1 was not significantly different (Figure 4A, 4C). The expression of IL-4/13B1 was also significantly higher $(p<0.05)$ than that of IL-4/13B2 in all tissues with the exception of gills, spleen, HK and intestine, important immune tissues/ organs in fish (Figure 4A, 4C). It is noteworthy that the expression of the IL-4/13B paralogues was particularly low in immune relevant tissues such as $\mathrm{HK}$, blood and intestine relative to IL-4/13A (Figure 4A).

In agreement with the high level expression in all the tissues examined, IL-4/13A expression was also detectable in all four cell lines, primary macrophages, HK cells and purified $\operatorname{IgM}^{+} \mathrm{B}$ cells (Figure 4B). However, the expression of IL-4/13B1 and B2 was not detectable in RTL, RTG-2, RTGill cells or purified B cells, but was detectable in HK cells, primary macrophages and the macrophage-like cell line RTS-11. The expression of IL$4 / 13 \mathrm{~A}$ was significantly higher $(p<0.05)$ than that of IL4/13B1 and IL-4/13B2 in RTS-11 cells and in HK cells, and IL-4/13B2 in primary macrophages (Figure 4B, 4C).

\section{The kinetics of expression of the three trout Th2 cytokines after viral haemorrhagic septicaemia virus (VHSV) infection}

Viral haemorrhagic septicaemia is one of the most important viral diseases of salmonid fish in European aquaculture caused by VHSV [50]. To gain an insight into their role in the host immune response to pathogens, we first investigated gene expression during VHSV infection. IL-4/13A expression did not exhibit any significant changes in the control fish, however the expression of IL4/13B1 and B2 increased over time in control fish with a significant increase at day 4 for IL-4/13B1 and at days 4 and 7 for IL-4/14B2 (Figure 5), suggesting that operational stress could modulate IL-4/13B1 and B2 expression to some extent. VHSV exposure resulted in a significant increase in IL-4/13B1 and B2 expression in the kidney during the early stages post infection (eg 1 to 5 days for IL-4/13B1, and 1-4 days for IL-4/13B2) that peaked at day 3 with a 26.3-fold increase for IL-4/13B2. IL-4/13A expression also increased but to a lesser extent (up to 2.8fold) and only at days 4 and 5 (Figure 5).

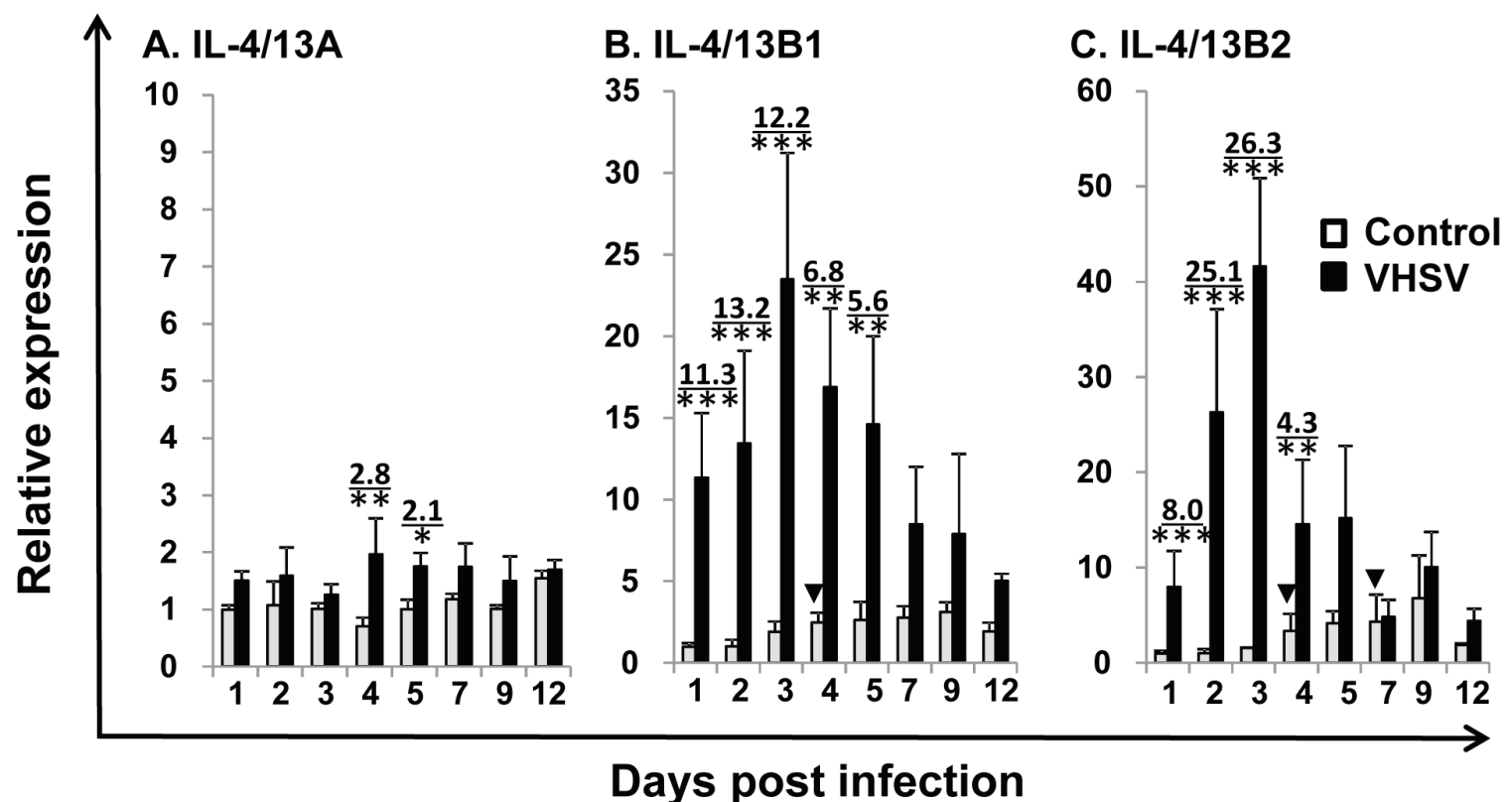

Figure 5: Modulation of the expression of trout IL-4/13A, B1 and B2 in kidney by VHSV infection. Rainbow trout were infected by intraperitoneal (i.p.) injection with $100 \mu \mathrm{l}$ of VHSV (DK-F1, 1 x $10^{9} \mathrm{TCID}_{50} / \mathrm{ml}$ ) while the control fish were mock-infected with the same amount of control media. Fish were sampled at 1 2, 3, 4, 5, 7, 9 and 12 days post challenge, when the kidney was removed for RNA preparation and real-time RT-PCR as described in Figure 4. The relative expression of IL-4/13 paralogues was normalized to the expression of EF-1 $\alpha$, and expressed as arbitrary units where one unit equals the average expression level of the mock-infected fish at day 1 post infection. The results represent the mean + SEM of four fish. The relative significance of a LSD post hoc test after a significant one way-ANOVA between the VHSV and mock-injected groups at the same time point is shown above the bars as: ${ }^{*} p<0.05$, $* * p<0.01$ and $* * * p<0.001$. The numbers above the bars are the fold changes, calculated as the average expression level of VHSV infected fish divided by that of the time-matched controls. The arrow heads indicate significant increases $\left({ }^{*} p<0.05\right)$ in the control fish relative to control fish at day 1 . 


\section{The expression of the three trout $\mathrm{Th} 2$ cytokines during proliferative kidney disease (PKD)}

PKD is a parasitic disease of salmonid fish caused by the myxozoan parasite Tetracapsuloides bryosalmonae [51]. The expression profiles of trout IL-4/13 paralogues were also investigated in the kidney of fish with clinical PKD relative to uninfected controls. The infected fish were sampled from a natural outbreak and the severity of kidney clinical pathology was assigned a swelling grade of 1-3 [51]. The expression of IL-4/13B1 and B2 was upregulated at grade 1, relative to control (grade 0) fish and to a greater extent in fish with advanced disease pathology (grades 1-2, 2 and 3) up to 13.7-fold (IL$4 / 13 \mathrm{~B} 1$ ) or 87.2 -fold (IL-4/13B2) (Figure 6B and 6C). In contrast, IL-4/13A expression was only increased 2.2 -fold in grade 1-2 fish (Figure 6A).

\section{Modulation of the expression of the three trout Th2 cytokines in vivo by vaccination and bacterial challenge}

Enteric redmouth disease (ERM) is a serious septicaemic bacterial disease of salmonid fish species caused by Yersinia ruckeri, a Gram-negative rodshaped enterobacterium. It can be prevented by bacterin vaccination [53]. Mammalian IL-4 and IL-13 are key adaptive cytokines. Thus, we examined the expression of trout IL-4/13A, B1 and B2 in vivo after bacterial challenge using an effective bacterial vaccination model in fish. The ERM vaccine protects the vaccinated fish from challenge and modulates the expression of adaptive cytokines involved in Th1 [53] and Th17 [54] type responses. An i.p. vaccination was performed as this is known to give a high degree of protection in the host, and when combined with an i.p. challenge means there is a clear contrast between control and vaccinated fish in terms of expecting them to live or die. In this way individual sample variation is reduced. Two important immune tissues, the HK and gills were used for gene expression analysis. The gills are an important site for ERM infection [53] and show high expression of all of the IL-4/13 paralogues, as shown in Figure 4 and by others [35]. The HK is the central immune organ of fish. Naïve fish started to show disease symptoms and to die from day 3 post bacterial infection. Thus, we focussed on early times post-infection. Gene transcriptional levels were expressed as arbitrary units where one unit in each tissue equals the average expression level in the PBS injected control group at $6 \mathrm{~h}$ (Figure 7). In naïve control fish, Y. ruckeri challenge resulted in a down-regulated expression in the gills of IL-4/13A (at 48 h), IL-4/13B1 (at $24 \mathrm{~h}, 48 \mathrm{~h}$ and $72 \mathrm{~h}$ ) and IL-4/13B2 (at $72 \mathrm{~h}$ ), and in the HK of IL-4/13B1 at $48 \mathrm{~h}$ post challenge (Figure 7). In vaccinated fish, Y. ruckeri challenge did not alter the expression of IL-4/13A, B1 and B2 in both tissues examined at early stages ( $6 \mathrm{~h}, 24 \mathrm{~h}$ and $48 \mathrm{~h}$ ). However at $72 \mathrm{~h}$, the expression of IL-4/13B1 and B2 in gills and HK, and of IL-4/13A in HK, was lower in Y. ruckeri challenged vaccinated fish compared to vaccinated and PBS injected fish (Figure 7). Interestingly, the expression of IL-4/13B1 was higher in vaccinated fish than in naïve fish during the early infection phase $(24 \mathrm{~h}$ and $48 \mathrm{~h})$ in both gills and HK. Similarly, the expression of IL-4/13A and IL-4/13B2 was also higher in gills at $48 \mathrm{~h}$ post-challenge (Figure 7).

\section{Modulation of the expression of the three trout Th2 cytokines in primary macrophages and HK cells}

To gain a further insight into IL-4/13 expression and modulation, we performed an expression analysis in vitro using $\mathrm{HK}$ cells and primary macrophages that are known to express all the three IL-4/13 paralogues (Figure 4). Bacterial infection had a negative effect on the expression of IL-4/13 paralogues in vivo (Figure 7). We, therefore, anticipated that host immune cells, such as HK cells that are a mixed population containing T cells, B cells, macrophages, neutrophils and others, should be modulated to express IL-4/13 paralogues in response to bacterial PAMPs (pathogen-associated molecular patterns). Thus HK cells were stimulated with formalin killed Renibacterium salmoninarum (a Gram positive bacterium that is the aetiological agent of bacterial kidney disease), Y. ruckeri and Aeromonas salmonicida (Gram negative bacteria, the latter being the aetiological agent of furunculosis), as well as with a non-pathogenic bacterium Arthrobacter davidanieli (used as a live vaccine for $R$. salmoninarum) [55]. A. davidanieli stimulation of HK cells markedly induced the expression of IL-4/13B paralogues from $4 \mathrm{~h}$ to $96 \mathrm{~h}$, that peaked at $24 \mathrm{~h}$ with an increase of 53.5-fold for IL-4/13B1 and 78.3-fold for IL4/13B2 (Figure 8A). It also induced the expression of IL$4 / 13 \mathrm{~A}$ at $8 \mathrm{~h}$ and $24 \mathrm{~h}$ but to a lesser extent (up to 3.3fold). Similarly pathogenic R. salmoninarum (Figure 8B), Y. ruckeri and A. salmonicida (data not shown) all highly induced the expression of IL-4/13B paralogues but had little to no effect on the expression of IL-4/13A (Figure $8 B)$.

Due to the lack of reagents to isolate $\mathrm{T}$ cells in fish, the T-cell expressing potential of IL-4/13 paralogues was investigated in HK cells by stimulation with a $T$ cell mitogen, phytohaemagglutinin (PHA), and two trout recombinant (r) cytokines, rIL-2 [56] and rIL-21 [57], that have major effects on T cells. PHA is a potent inducer of IL-4/13 paralogues in HK cells (Figure 8C) as well as spleen leucocytes. PHA stimulation markedly increased the expression of IL-4/13B paralogues from $4 \mathrm{~h}$ (53.0fold for IL-4/13B1 and 91.0-fold for IL-4/13B2) to 96 $\mathrm{h}$ that peaked at $8 \mathrm{~h}$ for IL-4/13B2 (236.7-fold) and 24 $\mathrm{h}$ for IL-4/14B1 (222.3-fold). PHA also increased the 


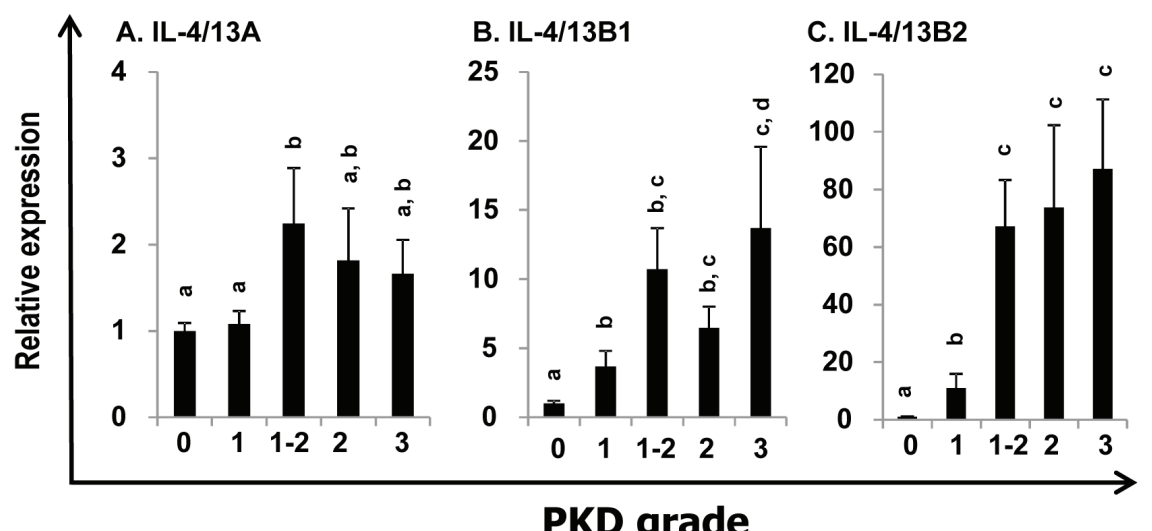

Figure 6: Modulation of the expression of trout IL-4/13A, B1 and B2 in kidney by parasite infection. Kidneys from rainbow trout infected with $T$. bryosalmonae or from unexposed (control) fish were collected during a natural infection [51-52]. The relative expression of IL-4/13 paralogues was normalized to the expression of EF-1 $\alpha$, and expressed as arbitrary units where one unit equals the average expression level of the control fish. Results are presented as means + SEM. The numbers of fish analysed were 12, 5, 9, 10 and 8 representing control, grade 1, 1-2, 2, and 3, respectively. The expression levels between different groups are statistically significant $(p<$ 0.05 ) where letters over the bars are different, as tested by one way-ANOVA.

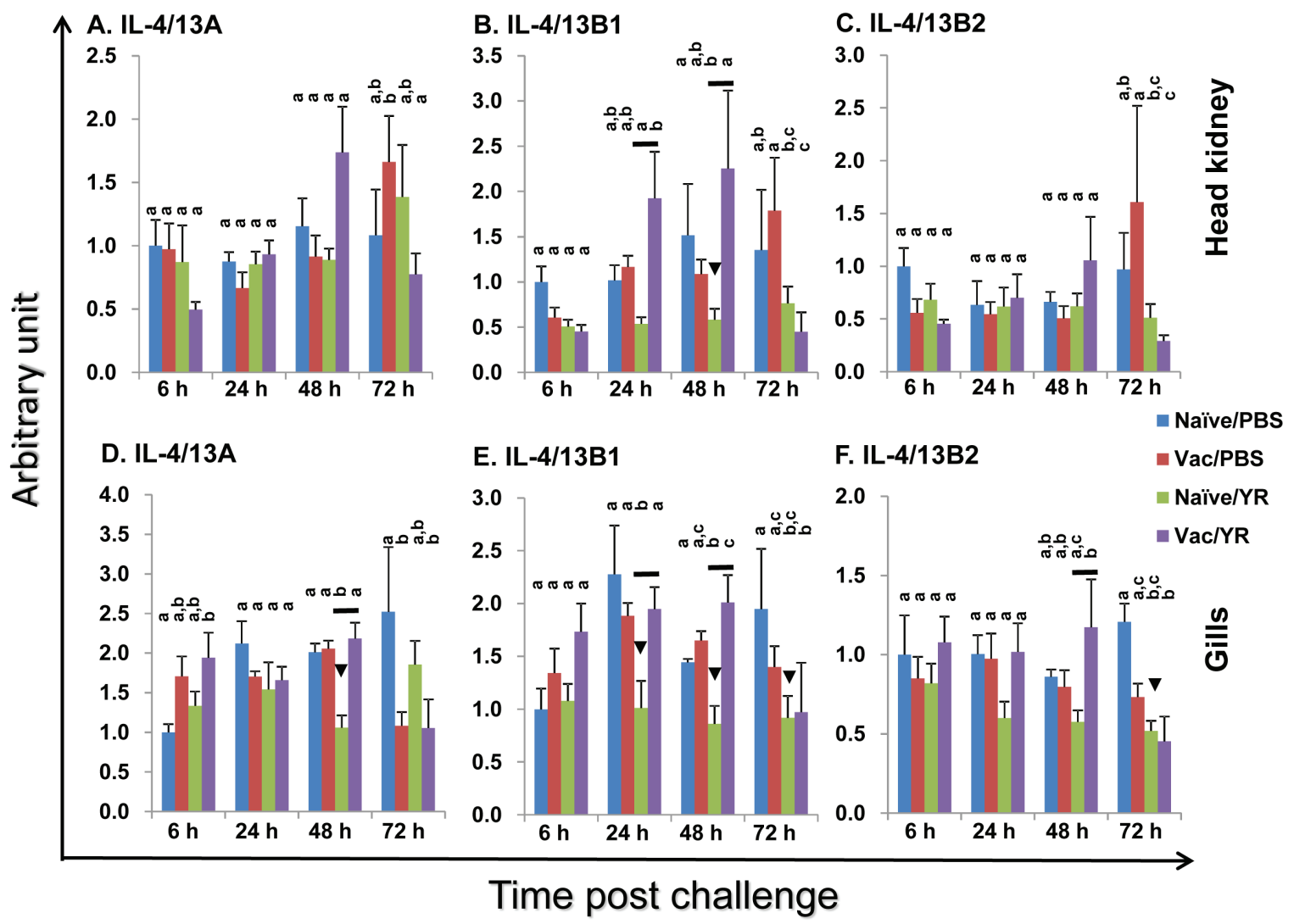

Figure 7: Modulation of the expression of rainbow trout IL-4/13A, B1 and B2 in head kidney A-C and gills (D-F) after vaccination and bacterial challenge. A group of fish was i.p. injected with AquaVac ${ }^{\mathrm{TM}} \mathrm{ERM}$ (Vac), with naïve fish (Naïve) serving as control. The fish were challenged 60 days later by i.p. injection of Y. ruckeri $\left(0.5 \mathrm{ml} / \mathrm{fish}, 1 \times 10^{6} \mathrm{cfu} / \mathrm{ml}\right.$; YR $)$ or injected with $0.5 \mathrm{ml}$ of PBS as control (PBS). The fish from each group were killed and the gills and HK collected for total RNA extraction. The gene expression analysis was performed as in Figure 4. The expression level was expressed as arbitrary units where one unit equals the average expression level in the PBS injected control group at $6 \mathrm{~h}$ in each tissue. The means + SEM of five fish are shown. The expression levels between different groups of the same tissue and time point are statistically different $(p<0.05)$ where letters over the bars are different, as determined by one way-ANOVA. The down arrow head indicates a significant down-regulation in the naïve fish after bacterial challenge at the same time point. The black line over the bars indicates a significant difference between the vaccinated and naïve fish after bacterial challenge. 
expression of IL-4/13A at $4 \mathrm{~h}$ and $8 \mathrm{~h}$, but only up to 4-fold. Recombinant rIL-2 increased the expression of IL$4 \mathrm{~B}$ paralogues from $4 \mathrm{~h}$ to $96 \mathrm{~h}$, with a peak of induction at $24 \mathrm{~h}$ for IL-4/13B2 (20.2-fold) and at $48 \mathrm{~h}$ for IL-4/13B1 (49.0-fold), but had no effects on IL-4/13A expression (Figure 8D). rIL-21 also increased the expression of IL$4 / 13 \mathrm{~B}$ paralogues, however the effect was relatively late, from $8 \mathrm{~h}$ to $96 \mathrm{~h}$, and peaked at $48 \mathrm{~h}$ with a 52.8 fold increase for IL-4/13B1 and 82.8 fold for IL-4/13B2. In contrast to the effect of rIL-2, rIL-21 also increased IL4/13A expression at a late stage ( $48 \mathrm{~h}$ and $96 \mathrm{~h}$ ) but with a maximal 5.1-fold increase (Figure 8E). The induction of the expression of IL-4/13B paralogues by PHA, rIL2 and rIL-21 was observed in at least three independent experiments.
We further investigated the modulation of expression of IL-4/13 paralogues in HK macrophages. As potential antigen presenting cells and sensors of inflammatory signals from innate and adaptive immune responses in fish, primary trout HK macrophages were stimulated with PAMPs, including polyinosinicpolycytidylic acid (poly IC, a mimic of viral infection) and peptidoglycan (PGN, major cell wall components of bacteria), and the inflammatory trout cytokines rIL-1 $\beta$ [58], rIL-6 [59], rIFN $\gamma$ [29] and rTNF $\alpha$ [42] (Figure 9). IL-4/13A expression in primary macrophages was downregulated at early time points by poly IC, rIL-1 $\beta$ and rTNF $\alpha$ at $4 \mathrm{~h}$, and by poly IC at $8 \mathrm{~h}$, but was refractory to stimulation with PGN, rIL-6 and rIFN $\gamma$ from $4 \mathrm{~h}$ to $24 \mathrm{~h}$ (Figure 9A). The expression of both IL-4/13B paralogues

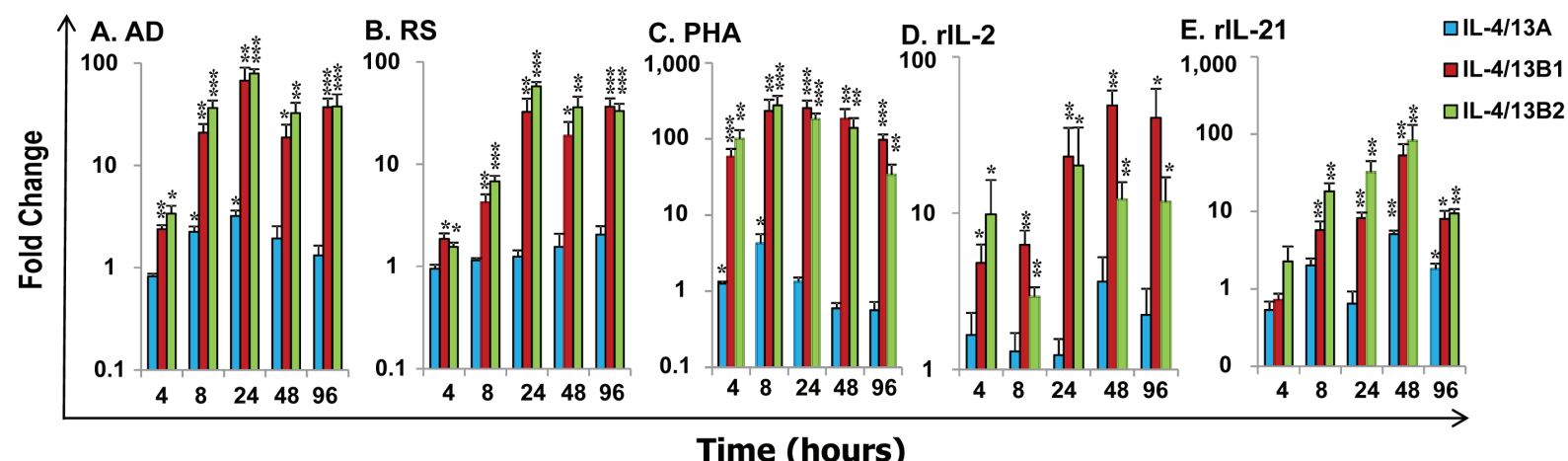

Figure 8: Modulation of the expression of rainbow trout IL-4/13A, B1 and B2 in HK cells. Freshly prepared HK cells were stimulated with formalin killed $A$. davidanieli (AD, A) and $R$. salmoninarum (RS, B), a T cell mitogen PHA (C), or the recombinant trout cytokines rIL-2 (D) and rIL-21 (E) for 4 h, 8 h 24 h, 48 h and 96 h. Quantification of gene expression was as described in Figure 4. Modulated expression was expressed as a fold change calculated as the mean expression levels in stimulated cells normalized to that of time-matched controls. The means + SEM of cells from four fish are shown. The relative significance of paired sample T tests between stimulated and time-matched control samples is shown above the bars. $* p \leq 0.05$, $* * p \leq 0.01$ and $* * * p \leq 0.001$.

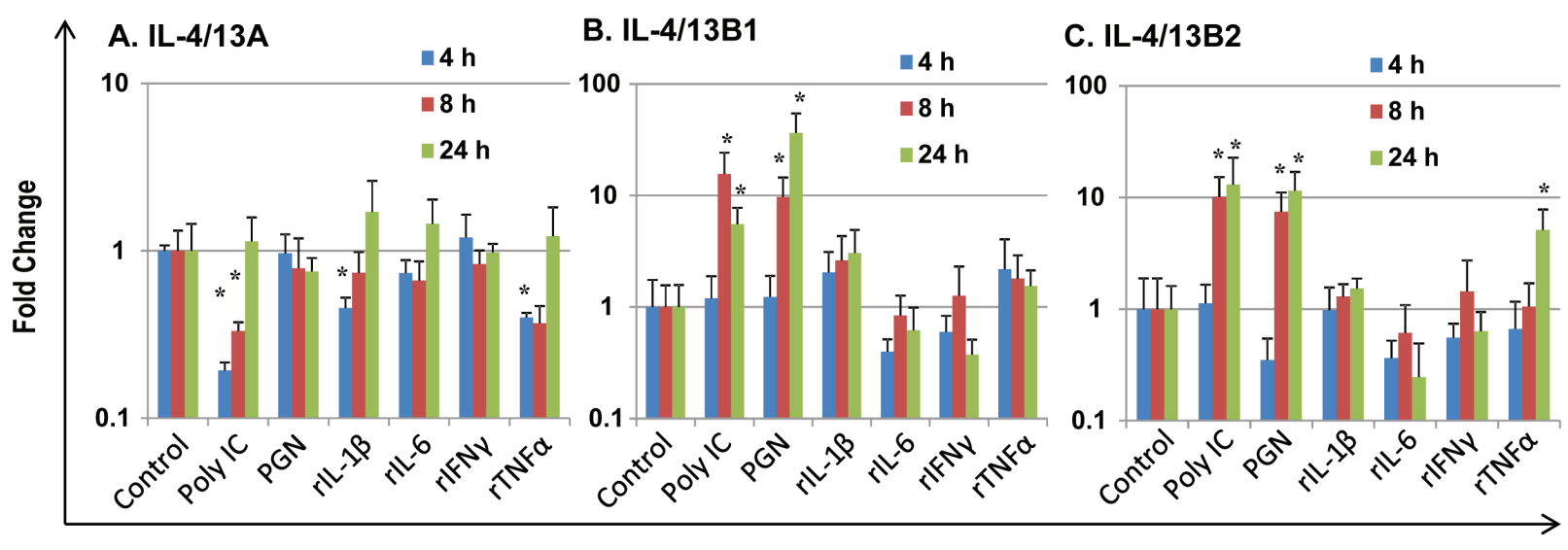

Treatment

Figure 9: Modulation of the expression of rainbow trout IL-4/13A A, B1 B and B2 C in primary HK macrophages. Four day old primary HK macrophages were stimulated with the PAMPs poly IC and peptidoglycan (PGN), or the recombinant cytokines rIL-1 $\beta$, rIL-6, rIFN- $\gamma$ and rTNF $\alpha$ for $4 \mathrm{~h}, 8 \mathrm{~h}$ and $24 \mathrm{~h}$. Quantification of gene expression was as described in Figure 4. Modulated expression was expressed as a fold change calculated as the mean expression levels in stimulated cells normalized to that of time-matched controls. The means + SEM of cells from four fish are shown. The relative significance of paired sample $\mathrm{T}$ tests between stimulated and time-matched control samples is shown above the bars. ${ }^{*} p \leq 0.05$. 
was refractory at $4 \mathrm{~h}$, but markedly up-regulated at $8 \mathrm{~h}$ and $24 \mathrm{~h}$ by the PAMPs. IL-4/13B1 expression was increased up to 15.6 -fold by poly IC and 36.5-fold by PGN (Figure 9B). Similarly, IL-4/13B2 expression was increased up to 13.0-fold by poly IC and 11.5 fold by PGN (Figure 9C). However, the expression of the IL-4/13B paralogues in HK macrophages was refractory to stimulation with all the proinflammatory cytokines tested, with the exception of $r \mathrm{TNF} \alpha$ that up-regulated IL-4/13B2 expression at $24 \mathrm{~h}$ (5.4-fold). The bioactivity of these cytokines have been reported previously $[29,42,58,59]$ and are confirmed in this study by the modulation of a number of marker genes.

\section{Production and purification of bioactive recombinant trout $\mathrm{Th} 2$ cytokines}

Proteins of the expected size of $15.2 \mathrm{kDa}$ (recombinant (r)IL-4/13A), $16.5 \mathrm{kDa}$ (rIL-4/13B1 (data not shown) and $16.8 \mathrm{kDa}(\mathrm{rIL}-4 / 13 \mathrm{~B} 2)$ were induced by IPTG stimulation of transformed BL21 cells, and purified under denaturing conditions with extensive washing in $1 \%$ Triton X-100 buffer to remove LPS (Figure 10A). The purified protein was refolded in vitro and re-purified under native conditions, and denaturants and other contaminants were removed by extensive washing of the purification column. When the refolded proteins (up to $1000 \mathrm{ng} / \mathrm{ml}$ ) were added to the macrophage cell line RTS-11, no upregulation of IL-1 $\beta$ and TNF- $\alpha$ expression (known LPS responsive genes in this system) was seen, confirming that

\section{A. SDS-PAGE}

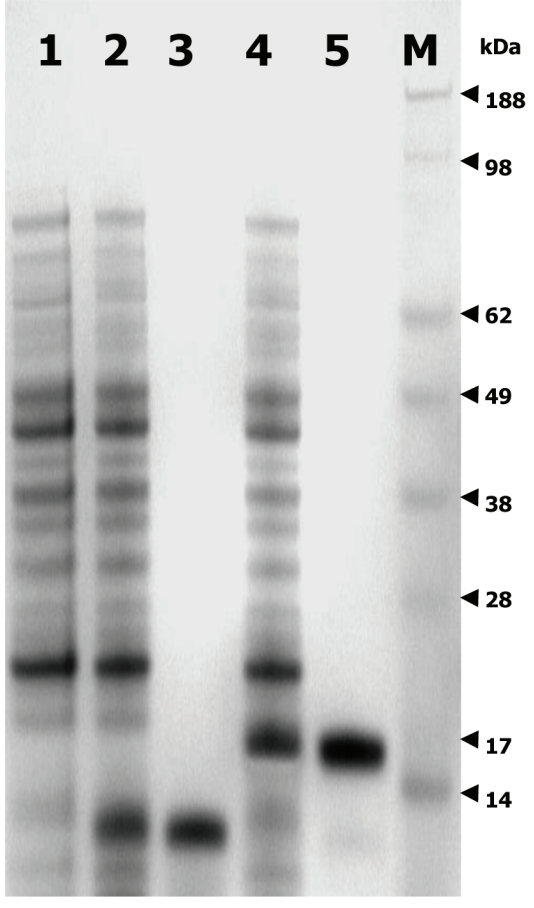

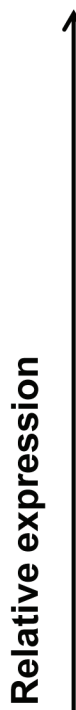

B. SAP

100
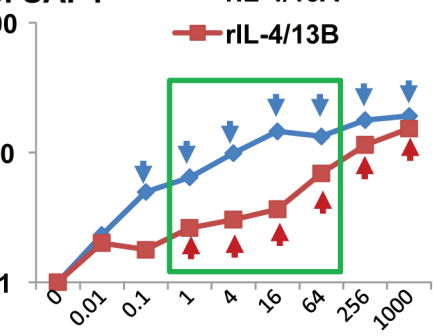

D. Hepcidin

100

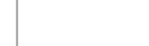

10

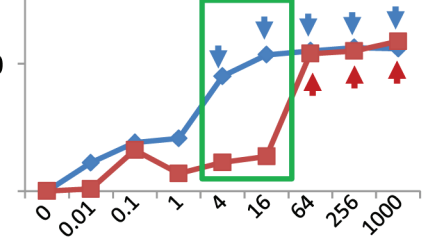

F. IFN $\gamma$ R1

10

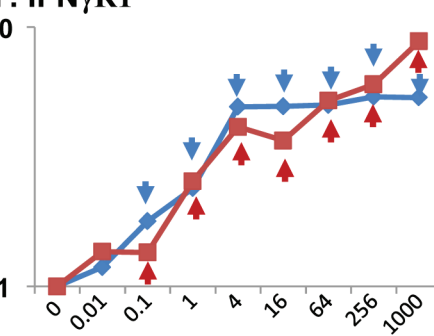

C. CATH1

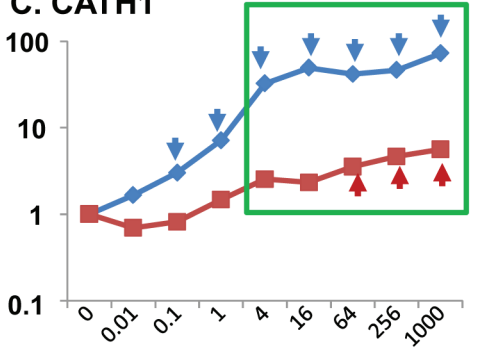

E. IL-10b

100

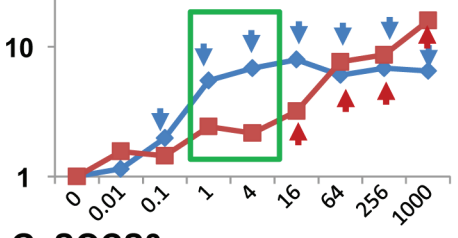

G. SOCS3

100

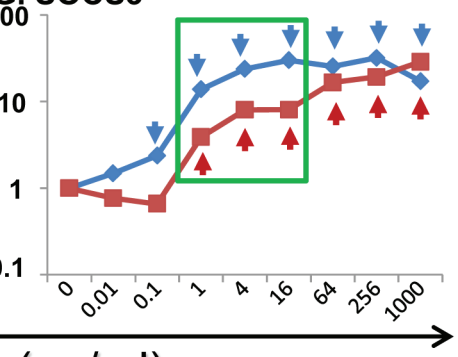

Dose $(\mathrm{ng} / \mathrm{ml})$

Figure 10: SDS-PAGE analysis $A$ and dose responses B-G of trout rIL-4/13A and rIL-4/13B2. A. SDS-PAGE analysis of rIL-4/13A and B expressed and purified from E. coli BL21 Star (DE3), and stained with SeeBlue (Invitrogen). 1, a sample from uninduced BL21 cells, 2 and 4, BL21 transformed by IL-4/13A- and IL-4/13B2-expressing plasmid, respectively and induced with 1 mM IPTG for $4 \mathrm{~h}$; 3 and 5, expression product purified from transformed cells expressing IL-4/13A and IL-4/13B2, respectively; and 6, Protein marker, SeeBlue Plus2 (Invitrogen). B.-G. Freshly prepared HK cells were stimulated with rIL-4/13A or rIL-4/13B2 at 0.01, 0.1, 1, 4, 16, 64, 256, and $1000 \mathrm{ng} / \mathrm{ml}$ for $4 \mathrm{~h}$. Gene expression was determined as described in Figure 4. The relative gene expression was calculated as the expression levels in stimulated cells normalized to that of un-stimulated controls. The means of cells from four fish are shown. For clarity the SEM bars are not shown here but are provided in Figure S11. The blue arrows and red arrows indicate significant differences ( $p$ $<0.05$, paired samples T tests) after stimulation with rIL-4/13A and rIL-4/13B2, respectively. A green box indicates significantly different expression levels ( $p<0.05$, paired samples T tests) between HK cells stimulated with the same doses of rIL-4/13A or rIL-4/13B2. 
LPS contamination in the recombinant preparations was negligible.

Initial analysis of bioactivity at $200 \mathrm{ng} / \mathrm{ml}$ in HK cells or splenocytes suggested that all the three recombinant proteins, rIL-4/13A, B1 and B2, were active in both cell populations in terms of modulation of the expression of several genes eg IL-4R $\alpha 1$ and cathelicidin-1 (CATH1). Due to the ease of preparation of large numbers of cells for in vitro stimulation, HK cells were chosen for further dose-response and time-course experiments. Also, since the IL-4/14B2 gene was more highly induced in vivo and in vitro (Figures 5, 6 and 8), and rIL-4/13B2 was predicated to be more stable than rIL-4/13B1 (with an instability index computed to be 37.8 for rIL-4/13B2 and 46.1 for rIL-4/13B1 [60]), and was found to be easier to refold, only trout rIL-4/13A and rIL-4/13B2 were taken further for bioactivity analysis.

A dose-response analysis of gene expression in $\mathrm{HK}$ cells suggested that both rIL-4/13A and B2 were bioactive at or above $0.1 \mathrm{ng} / \mathrm{ml}$, with an increased response seen with increasing doses (Figure 10B-10G). Whilst the ability of rIL-4/13A and B2 to modulate gene expression of some genes, eg IFN $\gamma \mathrm{R} 1$ ([61], Figure 10F) were not distinguishable, for other genes, eg CATH1 (Figure 10C), IL-4/13A was the more potent stimulant. However, for most of the genes analysed, eg hepcidin, IL-10b, serum amyloid P (SAP)1 and SOCS3 (Figure 10B, 10D, 10E, $10 \mathrm{G})$, the difference seen related to whether modulation of gene expression was found at lower doses (eg 1-64 ng/ml) or at higher doses (eg 64-256 ng/ml) with both proteins inducing similar responses.

\section{Time dependent modulation of transcript expression by rIL-4/13A and rIL-4/13B2 in HK cells}

A dose of $200 \mathrm{ng} / \mathrm{ml}$ was chosen for the time-course stimulation of HK cells for $4 \mathrm{~h}, 24 \mathrm{~h}, 48 \mathrm{~h}$ and $96 \mathrm{~h}$, as both IL-4/13A and B2 had similar abilities to modulate the expression of the majority of genes examined in the dose response experiment at this concentration (Figure 10B-10G). The expression of 64 genes were analysed in detail (Figures 11, 12, 13 and Table 2) in the time dependent experiment after an initial screening of over 200 immune genes. Two additional early time points (2 $\mathrm{h}$ and $8 \mathrm{~h}$ ) were also analysed for several early response genes (Figure 11).

Acute phase protein (APP) and antimicrobial peptide (AMP) genes: SAP1 expression was rapidly induced by rIL-4/13A with a 39.2-fold increase at $2 \mathrm{~h}$, reaching the highest increase of 89.2-fold at $4 \mathrm{~h}$ and returning to control levels by $96 \mathrm{~h}$. Its expression was also rapidly induced by rIL-4/13B2 with a 52.3 -fold increase at $2 \mathrm{~h}$, a peak of 80.4 -fold at $4 \mathrm{~h}$ and returning to control levels by $48 \mathrm{~h}$ (Figure 11A). SAP2 expression was also increased but to a lesser extent, whilst another APP (serum amyloid A) was down-regulated (Table 2).

Hepcidin expression was also rapidly induced by both rIL-4/13A and B2 and peaked at $4 \mathrm{~h}$ but returned to (or even below) control levels at 24-96 h (Figure 11B). CATH1 expression was increased at all time points and peaked at $24 \mathrm{~h}$ with a 26.5 -fold increase for rIL-4/13A

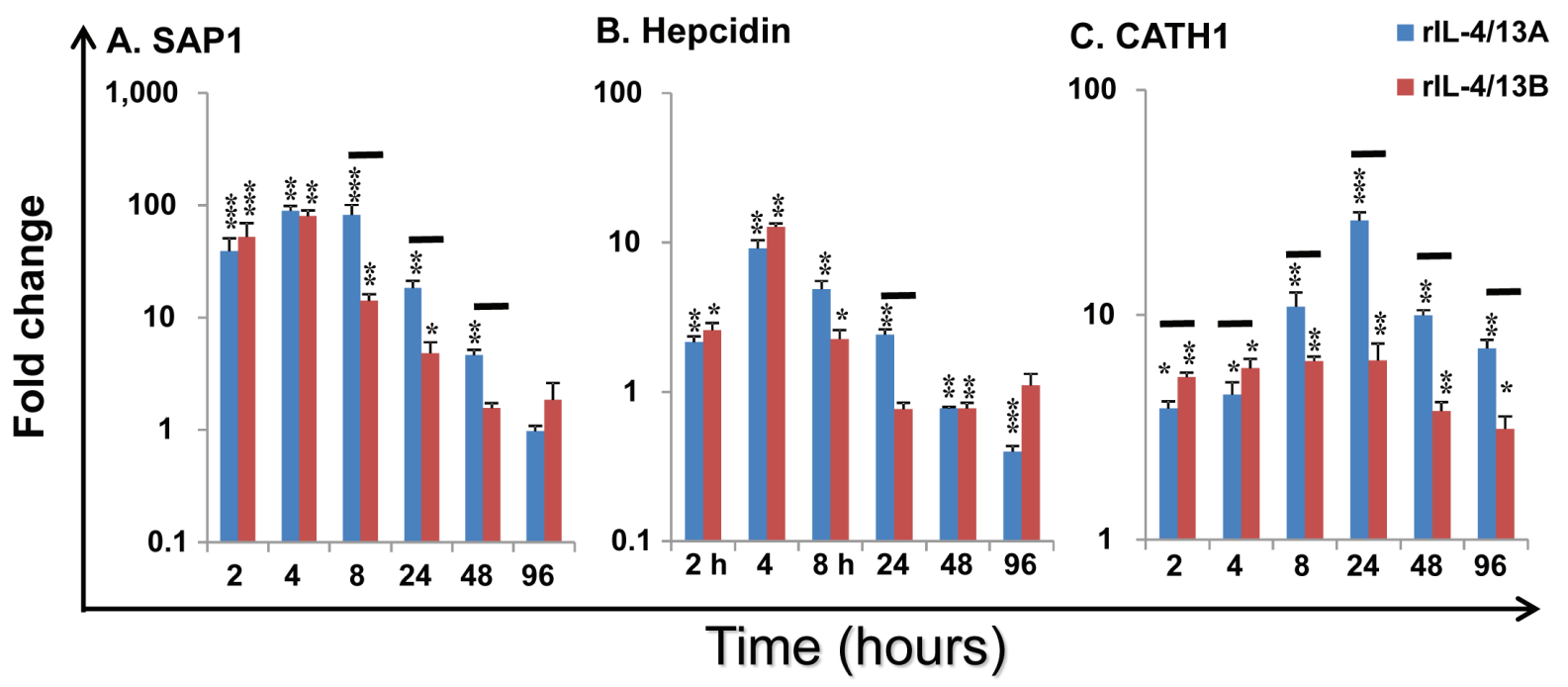

Figure 11: Modulation of the expression of SAP1 A, Hepcidin B and CATH1 C by rIL-4/13 isoforms. Freshly prepared HK cells were stimulated with rIL-4/13A or rIL-4/13B2 for $2 \mathrm{~h}$ to $96 \mathrm{~h}$ and gene expression determined as described in Figure 4. Modulated expression was expressed as a fold change, calculated as the expression levels in stimulated cells normalized to that of time-matched controls. The means + SEM of cells from four fish are shown. The relative significance of paired sample $\mathrm{T}$ tests between stimulated and time-matched control cell cultures are shown above the bars as: $* p \leq 0.05, * * p \leq 0.01$ and $* * * p \leq 0.001$. The black lines over the bars indicate significantly different expression levels between HK cells stimulated with rIL-4/13A and rIL-4/13B2. 
and a 6.5-fold increase for rIL-4/13B2 (Figure 11C). However, CATH2, that has a lower constitutive expression level, was down-regulated (Table 3). It is clear that the ability to modulate APP and AMP gene expression by rIL4/13A and B2 differ in a gene- and time-dependent manner (Figure 11).

Cytokine receptors: Both rIL-4/13A and B2 were able to modulate the expression of the receptors for IL4/13, the IL-6 cytokine family and IFN $\gamma$ (Figure 12A-12J). Eight potential receptor subunits of IL-4/13, two each of IL-4R $\alpha, \gamma \mathrm{C}$, IL-13R $\alpha 1$ and IL-13R $\alpha 2$, have been identified in salmonids [29]. Both rIL-4/13A and B2 rapidly upregulated the expression of both IL-4R $\alpha$ paralogues, with a peak of induction at $4 \mathrm{~h}$ by rIL-4/13B2 (10.3-fold for IL-4R $\alpha 1$ and 3.9-fold for IL-4R $\alpha 2$ ) and at $24 \mathrm{~h}$ by rIL4/13A (9.0-fold for IL-4R $\alpha 1$ and 5.1-fold for IL-4R $\alpha 2$, Figure 12A-12B). They also upregulated the expression of IL-13R $\alpha 2$ paralogues at later time points (24-96 h) with rIL-4/13A having a more prominent effect, with a 82.8-fold increase of IL-13R $\alpha 2 \mathrm{a}$ and 42.8-fold increase of IL-13R $\alpha 2 \mathrm{~b}$ seen at $96 \mathrm{~h}$ (Figure 12E-12F). They had no effects on IL-13R $\alpha 1$ a expression, but down-regulated IL-13R $\alpha 1 b$ expression at all time points (4-96 h, Figure $12 \mathrm{C}-12 \mathrm{D})$. No change of $\gamma \mathrm{C}$ expression was seen in the screening.

Both rIL-4/13A and B2 also rapidly up-regulated the expression of IFN $\gamma \mathrm{R} 1$ [61], with a peak at $4 \mathrm{~h}$ (4.7fold for rIL-4/13A and 5.6-fold for IL-4/13B2), but were less effective for IFN $\gamma \mathrm{R} 2$ expression (Figure 12G-12H). The expression of GP130 [62], a signal receptor chain for the IL-6 family cytokines, was up-regulated to a moderate degree from 4-96 $\mathrm{h}$ by both cytokines. In contrast, the expression of IL-6R $\alpha$, the private chain of IL-6, was down-regulated at $48 \mathrm{~h}$ by rIL-4/13A (Figure 12I-12J).

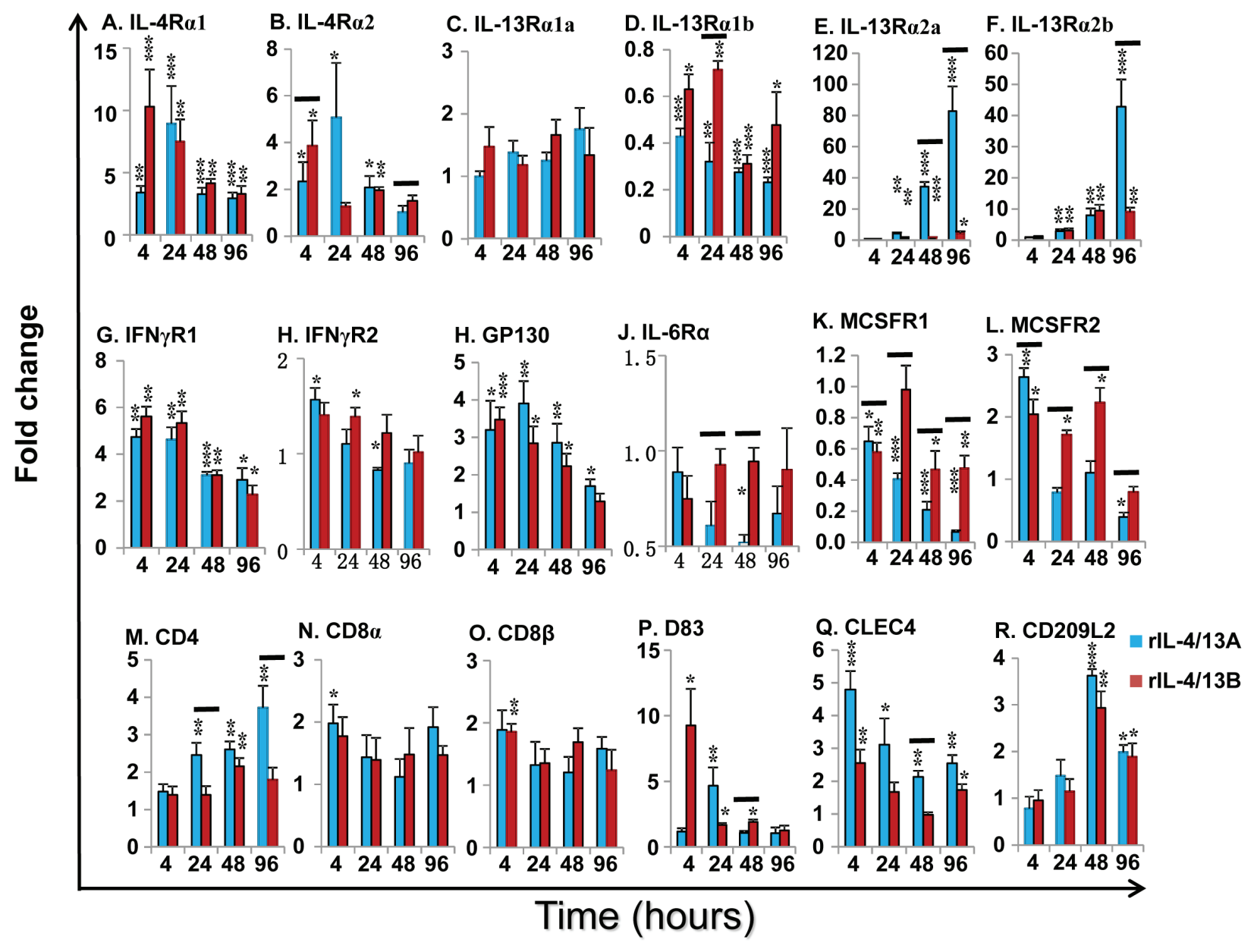

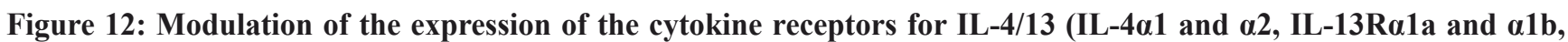
and IL-13R $\alpha 2 a$ and $\alpha 2 b)$, IFN $\gamma$ (IFN $\gamma$ R1 and 2), IL-6 (IL-6R $\alpha$ and GP130) and MCSF (MCSFR1 and 2), and cellular markers for T cells (CD4-1, CD8 $\alpha$ and CD8ß) and dendritic cells (CD83, CLEC4, and CD209L2) by rIL-4/13 isoforms. Freshly prepared HK cells were stimulated with rIL-4/13A or rIL-4/13B2 for $4 \mathrm{~h}$ to $96 \mathrm{~h}$ and gene expression determined as described in Figure 11. The means + SEM of cells from four fish are shown. The relative significance of paired sample $\mathrm{T}$ tests between stimulated and time-matched control cell cultures are shown above the bars as: ${ }^{*} p \leq 0.05, * * p \leq 0.01$ and $* * * p \leq 0.001$. The black lines over the bars indicate significantly different expression levels between HK cells stimulated with recombinant rIL-4/13A and rIL-4/13B2. 
Table 2: Fold change of transcript expression after stimulation of HK cells with rIL-4/13A and rIL-4/13B2.

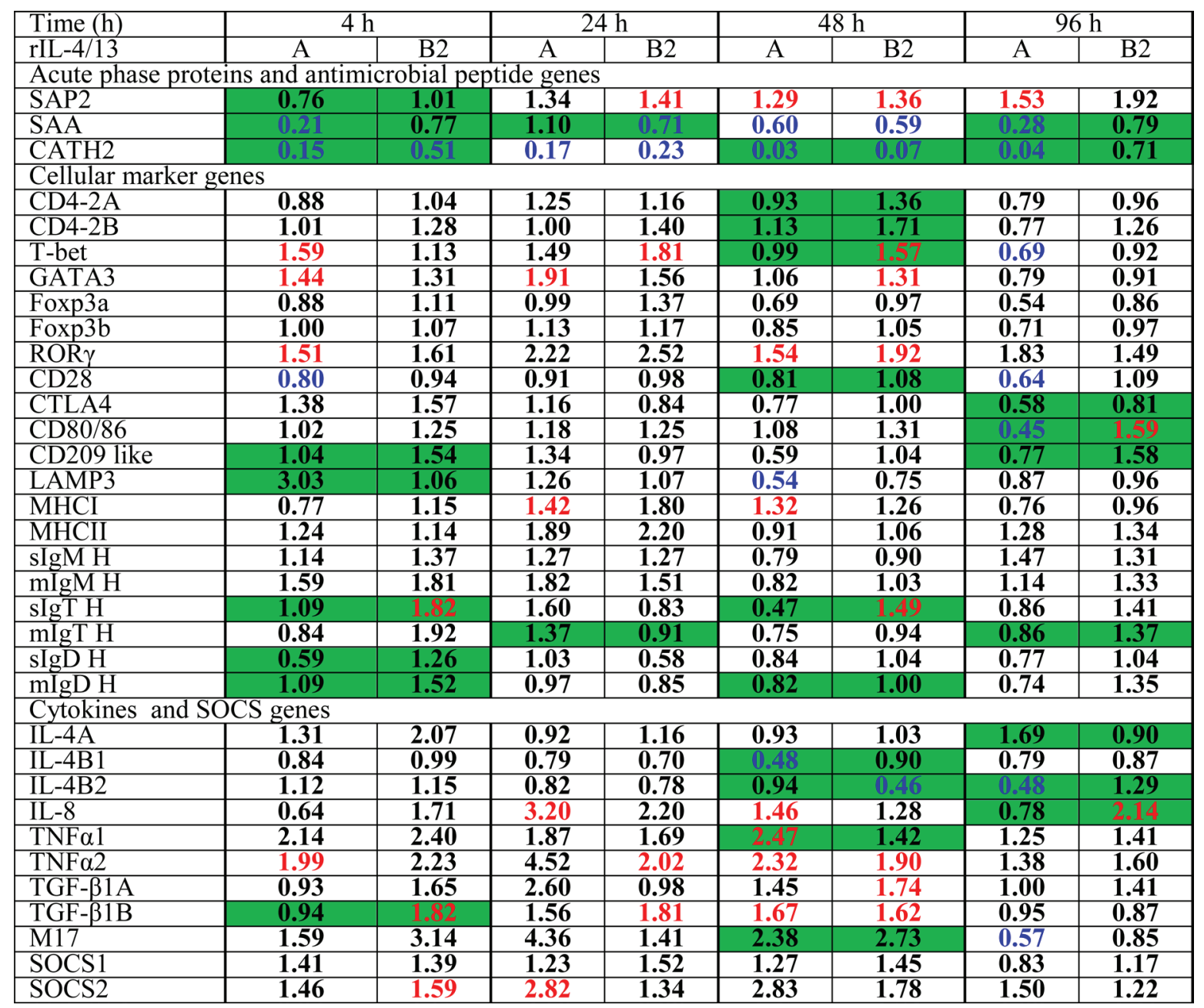

Numbers in red indicate significant ( $\mathrm{p}<0.05$, paired sample $\mathrm{T}$ tests) up-regulation, in blue down-regulation and in black no change. The numbers highlighted in green at the same time point indicate significant differences between samples stimulated with rIL-4/13A and rIL-4/13B2.

Curiously, they up-regulated at early time points $(4-48 \mathrm{~h})$ the expression of MCSFR2, that is highly expressed in HK primary macrophages but down-regulated the expression of the more lowly expressed MCSFR1 paralogue (Figure $12 \mathrm{~K}-12 \mathrm{~L})$.

Cellular marker genes: HK cells are comprised of immune cell types, including T cells, B cells, macrophages/ dendritic cells. The expression of marker genes of these cell populations was examined during the course of rIL4/13 stimulations. CD4-1 expression was increased at $24-96 \mathrm{~h}$ by rIL-4/13A (up to 3.7 -fold) and at $48 \mathrm{~h}$ by IL$4 / 13 \mathrm{~B} 2$ (2.2-fold) (Figure 12M). A small increase of the expression of $\mathrm{CD} 8 \alpha$ and $\mathrm{CD} 8 \beta$ was observed at $4 \mathrm{~h}$ by rIL$4 / 13 \mathrm{~A}$ and rIL-4/13B2, respectively (Figure $12 \mathrm{~N}-12 \mathrm{O}$ ). The expression of the master transcription factors for $\mathrm{Th}$ cell development, T-bet, GATA3 [63], FoxP3 [64] and ROR $\gamma$ [65], and T cell co-receptors, CD28 and CTLA, were not modulated relative to time-matched controls or were changed marginally at some time points (Table 2). The expression of $\mathrm{B}$ cell markers, the membrane form of $\operatorname{IgM}$, $\operatorname{IgT}$ and $\operatorname{IgD}$, and the secreted form of $\operatorname{IgM}$ and IgD was refractory to rIL-4/13 proteins. However, a small increase (less than 2-fold) in secreted IgT transcript expression was observed at $4 \mathrm{~h}$ and $48 \mathrm{~h}$ by IL-4/13B2 (Table 2).

Several genes relevant to the function of antigenpresenting cells (macrophages/dendritic cells) were induced. CD83 [66] expression was rapidly induced at $4-48 \mathrm{~h}$ by rIL-4/13B2 with a peak at $4 \mathrm{~h}$ with a 9.3 -fold increase, and by rIL-4/13A at $24 \mathrm{~h}$ (Figure 12P). The expression of CLEC4, a trout DC-SIGN/CD209 like molecule [67] was also rapidly induced at 4-96 $\mathrm{h}$ and peaked at $4 \mathrm{~h}$ (4.8-fold) with rIL-4/13A stimulation, and to a lesser extent by rIL-4/13B2 at $4 \mathrm{~h}$ and $96 \mathrm{~h}$ (Figure 12Q). Another CD209 like molecule (CD209L2) was also found to be up-regulated by both rIL-4/13 proteins at the later time points (48-96 h) (Figure 12R). The expression of CD209L1, and the MHC class II beta chain was refractory to IL-4/13 stimulation. However, small changes in expression of other genes, ie LAMP3 [68], CD80/86 


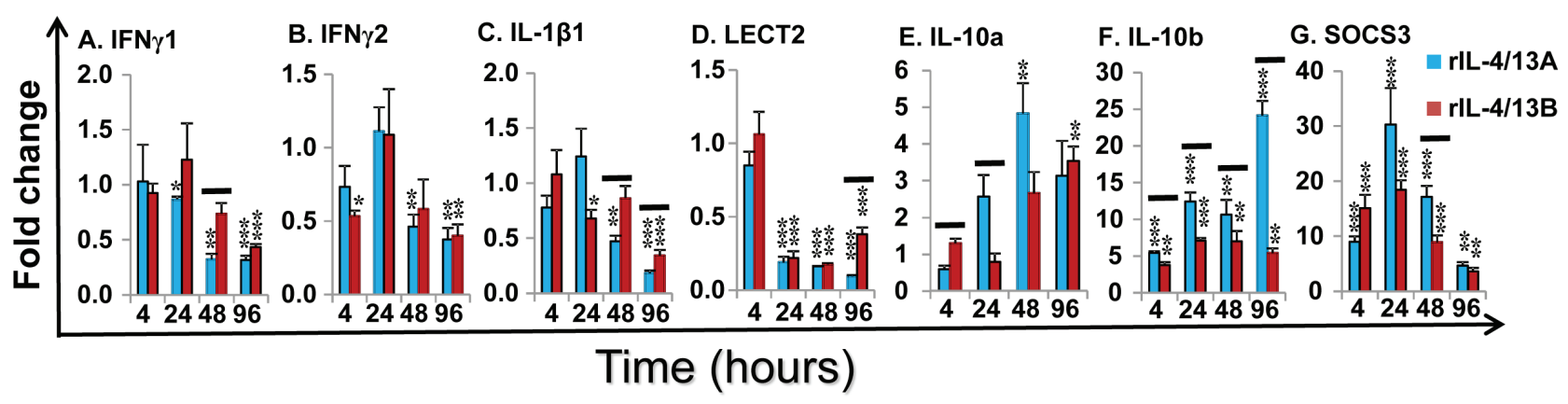

Figure 13: Modulation of the expression of the pro-inflammatory cytokines (IFN $\gamma 1$ and 2, IL-1ß1 and LECT2), antiinflammatory cytokines (IL-10a and b) and negative regulators (SOCS3) by rIL-4/13 isoforms. Freshly prepared HK cells were stimulated with rIL-4/13A or rIL-4/13B2 for $4 \mathrm{~h}$ to $96 \mathrm{~h}$ and gene expression determined as described in Figure 11. The means + SEM of cells from four fish are shown. The relative significance of paired sample $\mathrm{T}$ tests between stimulated and time-matched control cell cultures are shown above the bars as: ${ }^{*} p \leq 0.05,{ }^{*} p \leq 0.01$ and ${ }^{* * *} p \leq 0.001$. The black lines over the bars indicate significantly different expression levels between HK cells stimulated with recombinant rIL-4/13A and rIL-4/13B2.

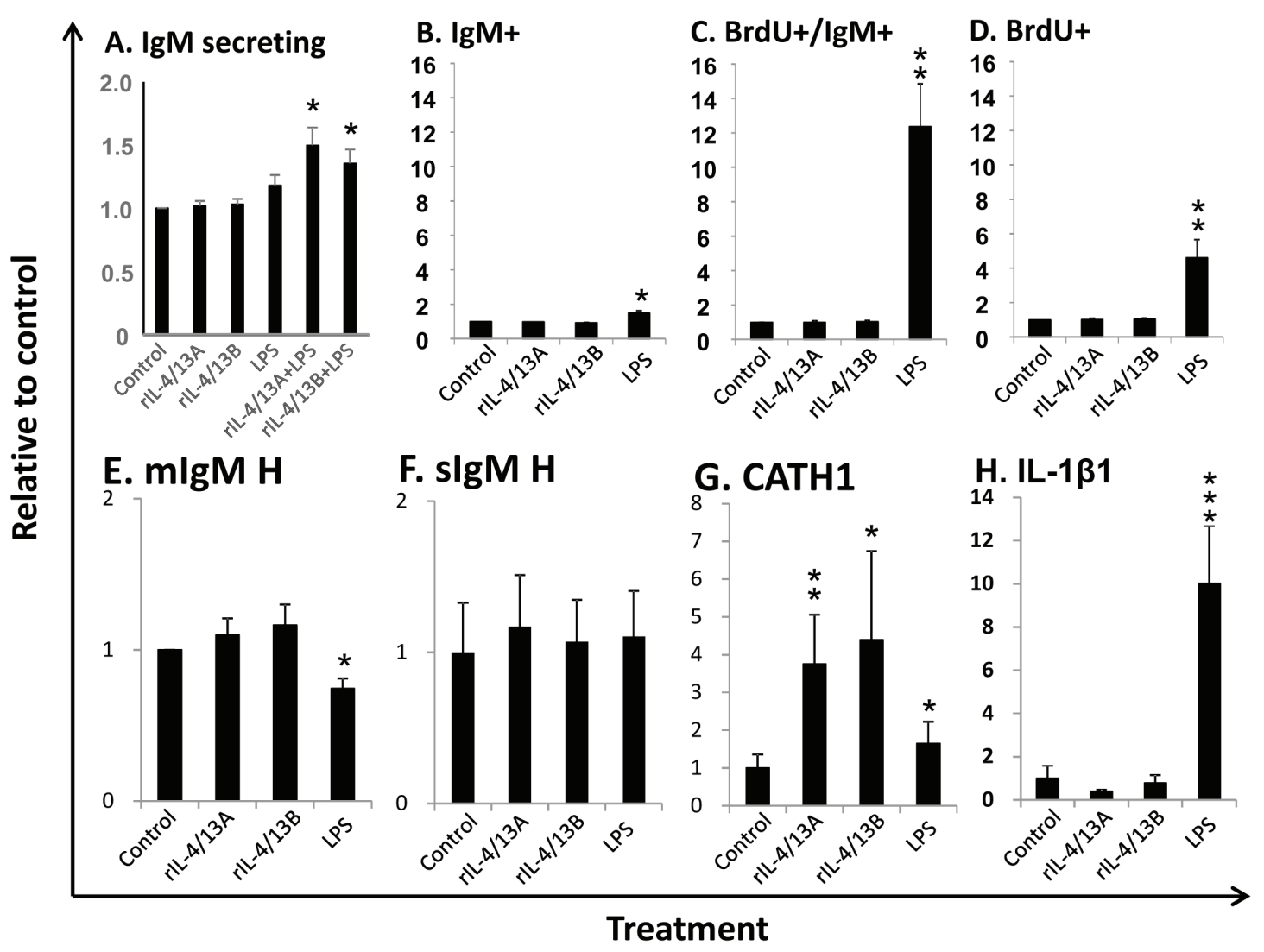

Figure 14: Effects of rIL-4/13 isoforms on IgM+ B cells. A. Spleen leucocytes were incubated with/without rIL-4/13A (200 ng/ $\mathrm{ml})$, rIL-4/13B2 $(200 \mathrm{ng} / \mathrm{ml})$, LPS $(100 \mu \mathrm{g} / \mathrm{ml})$, or LPS in combination of rIL-4/13A or IL-4/13B2 for 3 days at $20^{\circ} \mathrm{C}$ and IgM secreting cells were determined by ELISPOT. The IgM secreting B cells (means $+\mathrm{SEM}, n=5)$ relative to control $(=1)$ are shown. B-D. Spleen leucocytes were incubated with/without rIL-4/13A, rIL-4/13B2, or LPS as positive control for 3 days at $20^{\circ} \mathrm{C}$. The proliferating cells were then labeled with BrdU and incubated for a further $24 \mathrm{~h}$. The proliferating $\left(\mathrm{BrdU}^{+}\right)$cells and $\operatorname{IgM}^{+} \mathrm{B}$ cells were then determined by flow cytometry with typical results shown in Figure S12. The relative number (means + SEM, $n=11)$ of $\operatorname{IgM}^{+} \mathrm{B}$ cells $(\mathbf{B})$, proliferating B cells $(\mathrm{BrdU}$ and $\operatorname{IgM}$ double positive, $\mathrm{C})$ and total proliferating cells $\left(\mathrm{BrdU}^{+}, \mathrm{D}\right)$ are shown. E-H. Spleen leucocytes $(n=6)$ were incubated with/without $\mathrm{rIL}-$ 4/13A, rIL-4/13B, or LPS as positive control for $24 \mathrm{~h}$ at $20^{\circ} \mathrm{C}$. IgM ${ }^{+}$cells were sorted into TRIzol. The relative transcript expression (means + SEM, $n=6$ ) of the membrane form of IgM heavy chain $(\mathbf{E})$, secretory form of IgM heavy chain (F), CATH1 (G) and IL-1 $\beta$ (H) in FACS sorted $\operatorname{IgM}^{+} \mathrm{B}$ cells are shown. The relative significance of paired sample $\mathrm{T}$ tests between stimulated and control samples are shown above the bars as: $* p \leq 0.05 * * p \leq 0.01$ and $* * * p \leq 0.001$. 
[69] and MHC class I, were seen at the late time points (Table 2).

\section{Cytokines and suppressor of cytokine signalling (SOCS) genes}

Induced changes in cytokine gene expression of the paralogues of IL- $4 / 13$, TGF- $\beta 1$, TNF $\alpha$ and IL-8 were minor (Table 2), but for IFN $\gamma$, IL-1 $\beta$ and IL-10 they were relatively large and will be described in more detail. Two IFN- $\gamma$ paralogues are present in salmonids. IFN $\gamma 1$ expression was down-regulated at $24-96$ by rIL-4/13A and at $96 \mathrm{~h}$ by rIL-4/13B2. Similarly, IFN $\gamma 2$ expression was down-regulated at $48-96 \mathrm{~h}$ by rIL-4/13A and at $4 \mathrm{~h}$ and 96 h by rIL-4/13B2 (Figure 13A-13B).

Three IL-1 $\beta$ paralogues are present in salmonids with IL-1 $\beta 1$ highly expressed in HK cells and HK primary macrophages [41]. IL-1 $\beta 1$ expression was also significantly down-regulated at $48-96 \mathrm{~h}$ by rIL-4/13A and at $24 \mathrm{~h}$ and $96 \mathrm{~h}$ by rIL-4/13B2 (Figure 13C).

LECT2 (Leukocyte cell-derived chemotaxin-2) acts as a chemotactic factor for neutrophils and promotes inflammation and activation of macrophages [70-71]. LECT2 expression was significantly down-regulated from $24 \mathrm{~h}$ to $96 \mathrm{~h}$ by both rIL-4/13 proteins (Figure 13D)

Two paralogues of the anti-inflammatory cytokine IL-10 are present in salmonids [72]. Low level induction of IL-10a expression was observed at $48 \mathrm{~h}$ by rIL-4/13A and at 96 by rIL-4/13B2 (Figure 13E). In contrast, a prominent induction of IL-10b expression was observed from 4-96 $\mathrm{h}$ by both cytokines, that peaked at $24 \mathrm{~h}(7.1-$ fold) for rIL-4/13B2 stimulation and at $96 \mathrm{~h}$ (25.2-fold) for rIL-4/13A stimulation (Figure 13G). The rIL-4/13 proteins also induced the expression of another anti-inflammatory cytokine TGF- $\beta 1$ but with less potency (Table 2 ).

SOCS are cytokine-inducible negative regulators of cytokine signaling. SOCS3 [73] expression was highly induced from $4-96 \mathrm{~h}$ and peaked at $24 \mathrm{~h}$ with a 30.3 -fold increase for rIL-4/13A stimulation and a 18.5 -fold increase for rIL-4/13B2 stimulation (Figure 13F). A small increase of SOCS2 expression was also seen but no change in SOCS1 expression occurred with either protein (Table 2).

\section{Rainbow trout IL-4/13 isoforms increase IgM secreting $B$ cells but have no effects on $\operatorname{IgM}^{+} B$ cell proliferation in vitro}

Previous analysis revealed that trout B cells isolated from spleen expressed higher levels of potential receptor subunits of IL-4/13 isoforms, e.g. IL-4R $\alpha 2, \gamma \mathrm{C} 1$ and IL-13R $\alpha 2 \mathrm{a}$ [29], compared to B cells isolated from blood and head kidney. There are more $\operatorname{IgM}^{+} \mathrm{B}$ cells in the lymphocyte population in spleen $(30.3 \%)$ than in the HK (12.4\%) [74]. Thus, B cells from spleen were used throughout this study. A mean of 160 IgM secreting cells could be detected in each well of control cells ( $n$ $=5$ ) by ELISPOT. No significant effects were observed when the cytokines and LPS were added alone. However, the combination of LPS with rIL-4/13A or rIL-4/13B2 significantly increased the number of IgM secreting $\mathrm{B}$ cells (Figure 14A). We further analysed the potential of these cytokines to induce $\operatorname{IgM}^{+} \mathrm{B}$ cell proliferation $(n=11)$. In the control cells, the average $\left.\mathrm{IgM}^{+}, \mathrm{BrdU}^{+}\right)$ $\mathrm{IgM}^{+}$and $\mathrm{BrdU}^{+}$cells were $29.44 \%, 0.35 \%$ and $1.02 \%$, respectively (Figure S12). Unexpectedly, neither $\operatorname{IgM}^{+}$ cells nor proliferating $\mathrm{IgM}^{+}$cells (BrdU positive) were increased after incubation with rIL-4/13 isoforms, despite a significant increase of both ( 1.5 fold for $\operatorname{IgM}^{+}$cells and 12.4 for proliferating $\operatorname{IgM}^{+}$cells) by LPS (Figure 14B, $14 \mathrm{C})$. Furthermore, IL-4/13 isoforms had no effects on total BrdU positive cell numbers in spleen leucocyte cultures whilst LPS stimulation increased these cells by 4.6-fold relative to the control leucocytes (Figure 14D).

To confirm the effectiveness of these treatments, the expression of several marker genes was analysed in FACS-sorted B cells isolated from spleen leucocytes incubated with/without rIL-4/13A, rIL-4/13B2 and LPS for $24 \mathrm{~h}$. Trout IL-4/13 isoforms significantly increased the expression of CATH1, but had no effects on transcript expression of IgM H-chains (membrane- and secretory forms), and IL-1 $\beta 1$ (Figure 14E-14H). As expected, LPS up-regulated the expression of IL-1 $\beta 1$ and CATH1 [42], down-regulated the expression of the membrane form of the IgM H-chain, but had no effect on the secretory IgM $\mathrm{H}$-chain transcript. Taken together, these results show that the trout IL-4/13 isoforms increase IgM secreting B cell number but have no effects on proliferation of $\operatorname{IgM}^{+} \mathrm{B}$ cells in vitro.

\section{DISCUSSION}

In this study, four genomic loci have been identified in salmonids and three active IL-4/13 paralogues belonging to the two types of fish specific type-2 IL-4/13 genes have been cloned in both rainbow trout and Atlantic salmon. Our molecular characterisation of these genes suggests lineage-specific evolution of type 2 cytokines in vertebrates. We next extensively compared the expression and modulation of all the IL-4/13 paralogues in a single fish species in vivo and in vitro, providing a first comprehensive insight into their functional roles in fish. We then compared the function of the two types of fish-specific type- 2 cytokines in fish for the first time, and this revealed shared but also distinct bioactivities. This study will facilitate a broader understanding of the evolution of type-2 immunity in vertebrates, the functional characterisation of fish-specific type- 2 cytokines and the future potential to manipulate type-2-like immunity to protect fish from infectious disease. 


\section{Lineage-specific evolution of type-2 cytokines}

A single IL-4/IL-13 gene was likely to have existed in ancestral Gnathostomes, which has been duplicated in different lineages by WGD and/or tandem gene duplication events [10]. Thus, tandem gene duplication in mammals and birds led to the evolution of IL-4 and IL-13, and WGD in 3R teleost fish led to the IL-4/13A and IL$13 \mathrm{~B}$ paralogues $[10,32]$. A further $4 \mathrm{R}$ WGD in salmonids potentially produced four IL-4/13 paralogues. However, due to pseudogenisation of one of the two IL-4/13A loci, only three active paralogues, IL-4/13A, B1 and B2 are present in Atlantic salmon and rainbow trout (Figures 1, S1-S7).

The IL-4, IL-13 and IL-4/13 genes are fast evolving. This is demonstrated by the low homology within each lineage and between molecules. Mammalian IL-4 and IL13 only share low aa identities, of $40-57 \%$ and $53-64 \%$ between humans, cows and mice, respectively. These are remarkably lower compared to mammalian IL-7 (6175\%), IL-15 (72-78\%) and IL-21 (59-68\%), (Table S1). Furthermore, the homology between IL-4, IL-13 and IL-4/13 is low. For example, IL-4 and IL-13 only share $20-23 \%$ aa identity in mammals, and $20-27 \%$ in birds. The cartilaginous and teleost fish IL-4/13 molecules share only $16-29 \%$ aa identity to mammalian IL-4 and $15-28 \%$ identity to mammalian IL-13 (Table S1). Such rapid evolution is also exemplified by salmonid IL-4/13 molecules. In a similar manner to salmonid IL-4/13, three paralogues of IL-1 $\beta$ and IL-12 p35 have also been cloned in both salmon and trout, which share the same origin. The aa identities between 4R orthologues (eg A, B1, B2), $4 \mathrm{R}$ paralogues (eg B1 and B2), and 3R paralogues (eg. A and $\mathrm{B} 1$ or B2) are $90-95 \%, 75-79 \%$ and $29-32 \%$ for IL- $1 \beta$ molecules [41]; $95-97 \%, 87-90 \%$ and $36-39 \%$ for IL- 12 p35 [43]; but only $82 \%, 62-66 \%$ and $26-29 \%$ for IL-4/13 molecules (Table 2), respectively.

The orthologues are typically grouped together and separate from the other paralogues from a WGD in phylogenetic tree analysis, as seen with the two types of IL-1 $\beta$ [41], TNF $\alpha$ [42], IL-12 [43] and CISH [75] that arose from the 3R WGD. However, in the case of IL$4 / 13 \mathrm{~A}$ and IL-4/13B the orthologues do not group together, despite a well-supported 4R WGD orthologues-grouping of these molecules in salmonids (Figure S9). A lineagespecific grouping is apparent, eg bird or mammalian IL-4 and IL-13, and IL-4/13 molecules from different teleost fish lineages. The gene organisation, in terms of the size of exon 3 (Figure 2), and disulfide bonding potential of the peptides (Figures 3 and S10) are also lineage-specific. Such data provide support for a lineage-specific evolution of the type-2 cytokines in different vertebrates groups.

\section{Differential expression of the type 2 cytokines IL- 4/13A and IL-4/13B}

Differential expression and modulation of the paralogues may suggest a sub-functionalization and/or neofunctionalisation [75]. Our extensive analysis of gene expression revealed that different isoforms of the IL-4/13 paralogues are differentially expressed and modulated. Trout IL-4/13A is the major isoform highly expressed constitutively in tissues. Its expression is also detectable in all the four cell lines examined, in purified B cells, HK cells and primary macrophages (Figure 4). However its expression is less responsive to stimulation and infection (Figures 5, 6, 8, 9). These patterns of expression and modulation may suggest a homeostatic role of this IL-4/13 isoform to provide a basal or house-keeping level of type2 (IL-4/13) function.

Although the constitutive expression level of IL$4 / 13 \mathrm{~B} 1$ and B2 isoforms are lower compared to that of IL$4 / 13 \mathrm{~A}$, they are the major isoforms that are highly induced by viral and parasitic infection in vivo and by PAMPs in primary macrophages. They are also the major isoforms that respond to the T cell mitogen PHA and cytokines with major effects on $\mathrm{T}$ cells (Figure 8). Furthermore, IL$4 / 13 \mathrm{~B} 1$ and B2 expression is not detectable in cell lines of non-immune cells, or in B cells, but is present in the macrophage cell line RTS-11, in primary macrophages and in HK cells (Figure 4). These data suggest that trout IL$4 / 13 \mathrm{~B} 1$ and $\mathrm{B} 2$ isoforms are the major inducible isoforms that are expressed in T cells and other immune cells, and likely have a major role in $\mathrm{T}$ cell immunity in salmonids.

In agreement with the induced expression in vivo by viral and parasitic infection, the expression of trout IL$4 / 13 \mathrm{~B}$ paralogues is induced in antigen presenting cells (ie the primary HK macrophages) by PAMPs (Figure 9). In addition, HK cells were found to highly induce the expression of IL-4/13B paralogues in response to formalin killed bacteria, whether pathogenic or non-pathogenic, and Gram positive or Gram negative (Figure 8). These data show that infected rainbow trout are able to up-regulate IL-4/13 expression in response to PAMPs from viruses, parasites and bacteria. The in vivo down-regulation of IL4/13 paralogues in non-vaccinated fish during Y. ruckeri infection (Figure 7) could be indicative of mechanisms by which fish pathogens evade immunity.

Interestingly, the vaccinated fish expressed higher levels of the IL-4/13 paralogues than naïve fish during early stages of the disease, at $24 \mathrm{~h}$ and $48 \mathrm{~h}$ post $Y$. ruckeri infection in gills and HK (Figure 7). Whether this would also occur in other major secondary lymphoid organs such as the spleen remains to be determined. The functional role of IL-4/13 paralogues in this model of vaccine mediated protection is difficult to assess without IL-4/13 knockout trout lines. However, perhaps if the infection is under control, the pathogen is unable to evade immunity in vaccinated fish with the expression of IL-4/13 paralogues 
being maintained. Thus, the expression of IL-4/13 paralogues could be utilized as a novel molecular marker in evaluating vaccine efficacy. This may be especially important when designing a multi-valent vaccine or vaccines to enable cross protection.

\section{The type-2 cytokines IL-4/13A and IL-4/13B have overlapping but also distinct bioactivity}

By sharing receptors, mammalian IL-4 and IL-13 have overlapping but also distinct functions [1-2]. The orthologues of all mammalian receptor subunits are present in fish with two copies of each present in salmonids, which are differentially expressed and modulated in different tissues and cell lines [27-29]. Although the specific pairing of the ligands (three in salmonids) and receptors (eight in salmonids) is not clear in fish, the outcome of cytokine stimulation in a cell should be determined by 1) the presence of a combination of different receptor subunits on cell surfaces, 2) the affinity of the ligand/ receptor binding, which will determine the strength of the signalling, 3) the presence of other cells that may compete for ligand binding (but giving a different outcome), and 4) the microenvironment that may contain soluble receptors or other molecules that can regulate ligand/receptor binding or signalling.

Both rIL-4/13A and IL-4/13B2 modulated the expression of cellular markers of $\mathrm{T}$ cells and macrophages/ dendritic cells indicating these are target cells that express relevant receptors. This is similar to mammalian IL-4 that acts on a variety of cell types [76]. The distinct bioactivities between rIL-4/13A and rIL-4/13B2 observed in HK cells are mainly the result of the magnitude of the response or differential kinetics (Figures 10, 11, $12,13)$. These differences are likely explained, at least in part, by differences in receptor usage or affinity to different receptor complexes expressed on different cell populations. The dissection of the mechanisms will require the development of new molecular tools to isolate different cell populations from HK cells in the future.

AMPs and APPs are evolutionarily conserved effector molecules of the innate immune system that have important roles in the resolution of infection and activation of the adaptive immune response. The rapid up-regulation of the expression of SAP1, hepcidin and CATH1 by both IL-4/13A and IL-4/13B2 suggests a role of these type- 2 cytokines in the resolution of infection. Rapid up-regulation of trout IL-4R $\alpha 1$ and IL-4R $\alpha 2$ expression by rIL-4/13A and B2 (Figure 12) was also seen and may suggest a self-amplification mechanism of signalling specific to these cytokines. Interestingly, the expression of the potential decoy receptors IL-13R $\alpha 2 \mathrm{a}$ and $\alpha 2 \mathrm{~b}$ was significantly up-regulated at late stages (24-96 h) of stimulation of HK cells, with rIL-4/13A having more prominent effects compared with rIL-4/13B2 (Figure 12).
Treatment of HK cells with rIL-4/13A and B2 resulted in the down-regulation of the proinflammatory cytokines IFN- $\gamma 1$, IFN- $\gamma 2$ and IL- $1 \beta 1$, at the late time points, but up-regulation of anti-inflammatory genes including IL-10a, IL-10b, SOCS3 (Figure 13), and (to a lesser extent) SOCS2 (Table 2), perhaps as a negative feedback to limit the signalling of fish type- 2 cytokines. Clearly these results suggest an anti-inflammatory role of fish type-2 cytokines, as seen with mammalian IL-4 and IL-13 that are known to suppress the expression of proinflammatory genes [76]. There is also the potential for inhibition of Th1 type responses in fish by IL-4/13, as seen with IL-4 in mammals. Interestingly, the expression of several cytokine receptors was also affected. For example, IL-6R, and MCSFR1 were down-regulated, especially by rIL-4/13A (Figure 12). IL-6 signals via a complex of the common chain gp130 and the private IL$6 \mathrm{R} \alpha$, and is involved in inflammation and macrophage activation and proliferation in trout [62]. MCSFR1 and MCSFR2 are potentially the receptors for at least three fish cytokines, MCSF1, MCSF2 and IL-34, which regulate the mononuclear phagocyte system with crucial roles in inflammation, and in maintaining organismal homeostasis [77-78]. In contrast, IFN $\gamma \mathrm{R} 1$, and to a lesser extent IFN $\gamma$ R2, MCSFR2 and gp130 were also up-regulated to some extent. Modulation of the expression of these receptors by rIL-4/13A and B2 indicates an important role in the fish cytokine network via cross talk with the IFN- $\gamma$ and IL- 6 family members.

\section{The functional role of IL-4/13 isoforms in B cells}

Mammalian B cells first produce $\operatorname{IgM}$ and $\operatorname{IgD}$ and then, after activation, they can switch to produce IgG, IgA, or IgE. IL-4 can regulate Ig class switching in mice to IgG1 and IgE, and in humans to some subclasses of IgG and to $\operatorname{IgE}[79]$. Teleost fish also produce $\operatorname{IgM}$ and $\operatorname{IgD}$ but also a unique Ig termed IgT, with IgM and IgD coexpressed on the same cells but $\operatorname{IgT}$ on separate B cells [80]. Thus class-switching per se may not be a function of Th2 type cytokines in bony fish. The trout rIL-4/13A and B2 had no effect on transcript expression of the secreted or membrane forms of IgM and IgD in HK cells (Table 2 ), or on the proliferation of spleen leucocytes and $\operatorname{IgM}^{+}$ $\mathrm{B}$ cells (Figure 14) in vitro. However, both cytokines increased the numbers of IgM secreting B cells, as seen in ELISPOT assays. Thus trout type- 2 cytokines on their own have no direct proliferative effects for spleen leucocytes in vitro, including $\operatorname{IgM}^{+} \mathrm{B}$ cells, but seem to be a survival or reactivation factor for IgM secreting B cells. Interestingly, in mammals, these "type-2 immune response-related" cytokines are not only produced by $\mathrm{CD} 4 \mathrm{Th} 2$ cells but also by ILC2s [12] that play an important role in early type2 responses. In mice, ILC2 can be activated in response to IL-4 produced by basophils releasing large amounts of Th2 cytokines such as IL-5 and IL-13, as well as IL-6 [81]. 
This cytokine production together with the interaction of ICOS (expressed on ILC2 cells) and ICOSL (expressed on the surface on B lymphocytes) has been shown recently to increase the survival and promote the production of IgE by B cells [82-83]. Furthermore, IL-13 produced by ILC2 has been shown to activate non-dividing plasma cells [84], and ILC-2-derived IL-5 and IL-6 have been shown to support self-renewal of B1 cells from the peritoneal cavity and Ig production by splenic B cells [85]. This does not rule out the possibility that the trout type- 2 cytokines could have proliferative effects in the presence of additional factors that are not present in the culture medium in vitro. Interestingly, a recent report in zebrafish demonstrated that i.p. administration of rIL-4/13A significantly increased the number of B cells in PBL [39]. However, whether the increased number of $B$ cells is the result of IL-4/13 proliferation effects (in vivo), or indirect effects (eg via IL$4 / 13$ induced factors) is not known and will be interesting to study further. The effects of type- 2 cytokines on $\operatorname{IgT}^{+} \mathrm{B}$ cells in fish also needs future investigation.

\section{Implications towards the evolution of type-2 immunity in early vertebrates}

Th2-type immunity is hypothesised to give a fitness advantage by reduction of collateral tissue damage from metazoan parasites, and acts as a counter-regulator to Th1 responses that are primarily antimicrobial [26]. Whilst Th2 responses have been known for a long time [2], there are still many questions relating to the mechanisms that initiate and control these responses in mammals [86], which comparative studies in other vertebrates may aid. There are two types of type-2 cytokines present in teleost fish, IL-4/13A and IL-4/13B [10], that may be further increased in some species by gene duplication or WGD (eg in salmonids, as demonstrated in this study). Fish type- 2 cytokines have overlapping bioactivities, such as the induction of APPs, AMPs and IL-10, and inhibition of proinflammatory cytokines (IFN- $\gamma$ and IL-1 $\beta$ ), that could be due to conserved receptor usage [28-29] as seen in mammals with IL-4 and IL-13. Fish IL-4/13A is broadly and highly expressed and has potent bioactivities at low concentrations, which may provide a basal level of type-2 immunity in fish. Fish IL-4/13B exhibits low constitutive levels but is highly inducible in response to PAMPs and $\mathrm{T}$ cell stimulants (mitogens and cytokines) with its expression perhaps being more restricted to immune cells. Its maximal bioactivity required relatively high concentration that may reflect low levels of its preferred receptor in unstimulated HK cells. In carp, a Th2-like cell clone that expresses a high level of IL-4/13B but not IL4/13A after PHA stimulation has been identified recently, supporting the concept that IL-4/13A and IL-4/13B can be secreted by different cell types [37]. Mammalian IL-4/IL-13 expression is controlled by chromatin remodelling in the locus control region within the 3' end of the RAD50 gene, and a potential regulatory element within the KIF3A gene [12]. The linkage to RAD50 (IL4/13A) or KIF3A (IL-4/13B) likely reflects the need for regulatory elements associated within these genes in fish, but the loss of the linkage to both has perhaps impacted on the unique expression patterns seen in trout outlined above. Heterogeneity of Th2 cell responses are known in mammals, as seen with the so-called "inflammatory Th2 cells" and "noninflammatory Th2 cells" [83], with interest in the potential to re-programme subsets that may cause pathology to a "protective" phenotype. Understanding the origins of these responses and the different Th2 phenotypes present in other vertebrate groups may be informative in this regard. Overall, these data suggest an enhanced type-2 immunity in fish can occur following detection of particular danger signals and results in the activation and expression of the IL-4/13B gene(s), which may be more important for specific $\mathrm{T}$ cell mediated immunity, at least in salmonid fish.

\section{MATERIALS AND METHODS}

\section{Fish}

Rainbow trout were maintained in aerated fibreglass tanks supplied with a continuous flow of recirculating freshwater at $14^{\circ} \mathrm{C}$. Fish were fed twice daily on a commercial pellet diet (EWOS), and were given at least 2 weeks of acclimatization prior to treatment. All the experiments described comply with the Guidelines of the European Union Council (2010/63/EU) for the use of laboratory animals, and were carried out under UK Home Office project licence PPL 60/4013, approved by the ethics committee at the University of Aberdeen.

\section{Cloning of the IL-4/13 genes in salmonids}

\section{Cloning of salmonid IL-4/13A cDNA and DNA}

Four salmon expressed sequence tag (EST) entries (acc. nos. EG837624-25 and EG860817-18) were identified that encode for salmon IL-4/13A. To obtain trout IL-4/13A cDNA, primers (tIL4aF1 and 2, Table 3) were designed according to the salmon ESTs and used for 3'-RACE (Rapid amplification of cDNA ends) using trout gill SMART cDNA, as described previously [87]. A 0.75 $\mathrm{kb} 3$ '-RACE product was obtained and contained the trout IL-4/13A CDS and 3'-UTR. A $0.45 \mathrm{~kb} 5$ '-RACE product was obtained using primers (tIL4aR1 and R2, Table 3) designed on the trout IL-4/13A sequence. The overlapping cDNA sequence (acc. no. FN820500) contained the 5'UTR, complete CDS and the 3'UTR. The PCR protocol, cloning of the PCR product and sequence analysis was 
as described previously $[57,78]$. Fish IL-4/13A gene is closely linked to RAD50 [19, 32]. A $4.39 \mathrm{~Kb}$ genomic DNA (acc. no. FN820501) was amplified using primers located on RAD50 and in the 3'- UTR of trout IL-4/13 cDNA.

\section{Cloning of salmonid IL-4/13B1 and IL-4/13B2 cDNA}

The Atlantic salmon whole genome shotgun (WGS) sequence was searched (TBLASTN [88]) using known fish IL-4/13 molecules. Candidate WGS contigs (Table 1) were identified and exons predicted as described previously [43]. Primers (Table 3) were designed against the predicted 5'-UTR and used for 3'-RACE using SMART cDNA as above. The cloning of the PCR products yielded fulllength cDNA sequences from two salmon IL-4/13 genes designated as IL-4/13B1 and IL-4/13B2, according to their linkage to the KIF3A gene [10,32]. The trout counterparts of the salmon IL-4/13B1 and B2 were amplified from a mixed tissue cDNA sample using primers designed in the 5'- and 3'- UTR of the salmon sequences (Table 3), and then were cloned and sequenced. The genomic sequences of trout IL-4/13B genes were identified from the recent release of the trout WGS contigs [89].

\section{Sequence analysis}

The nucleotide sequences generated were assembled and analyzed with the AlignIR programme (LI-COR, Inc.). Homology search was performed at the National Center for Biotechnology Information (NCBI) using the BLAST program (http://blast.ncbi.nlm.nih.gov/Blast.cgi) [85]. The gene organization was predicted using the Spidey program at NCBI. Protein prediction was performed using software at the ExPASy Molecular Biology Server (http://www. expasy.org/tools) [60] and signal peptides were predicted using the SignalP4.0 program [90]. Disulfide bonding and cysteine connectivity were predicted using the DISULFIND program (http://disulfind.dsi.unifi.it) [49]. Global sequence comparison was performed using the scoring matrix BLOSUM62 within the MatGAT program, with a gap open penalty of 10 and gap extension penalty of 1. [91]. Multiple sequence alignments were generated using CLUSTALW [92]. The synteny of IL-4/13 loci was analysed using Genomicus (database version 75.01) [93]. A neighbour-joining phylogenetic tree was constructed on full-length amino acid multiple alignments using the MEGA6.0 software [44]. The evolutionary distances were computed using the JTT matrix-based method with all ambiguous positions removed for each sequence pair.
Transcript distribution of rainbow trout IL4/13 paralogues in tissues, cell lines and purified immune cells

RNA preparation, cDNA synthesis, and real-time PCR analysis were performed as described previously $[29,57]$. The primers (Table S2) for real-time-PCR were designed so that at least one primer crossed an intron, to ensure that genomic DNA could not be amplified under the PCR conditions used. To directly compare the expression level of the different IL-4/13 paralogues, a reference was constructed using equal molar amounts of PCR product from each gene, including the house keeping gene elongation factor- $1 \alpha(\mathrm{EF}-1 \alpha)$. The relative expression level of each sample was normalized against the expression level of EF-1 $\alpha$.

\section{Tissues from healthy fish}

Six healthy rainbow trout $(\sim 140 \mathrm{~g})$ were killed and seventeen tissues (blood, thymus, gills, scales, skin, muscle, tail fins, adipose fin, brain, adipose tissue, spleen, liver, heart, intestine, gonad, head kidney and caudal kidney) were collected and processed as described previously [41, 94]. The RNA preparation, cDNA synthesis and real-time PCR analysis of gene expression was also as described previously $[29,61]$.

Cell lines, head kidney (HK) cells, primary macrophages and purified $\operatorname{IgM}^{+} B$ cells

Four rainbow trout cell lines, a monocyte/ macrophage-like cell line RTS-11 from spleen [95], an epithelial cell line RTL from liver [96], and fibroid cell lines RTG-2 from gonad [97] and RTGill from gills [98], were cultured in Leibovitz medium (L15, Life Technologies) supplemented with $100 \mathrm{IU} / \mathrm{ml}$ penicillin $/ 100 \mu \mathrm{g} / \mathrm{ml}$ streptomycin $(\mathrm{P} / \mathrm{S})$, and $10 \%$ fetal calf serum (FCS). The cells were dissolved in TRI reagent (Sigma) for total RNA preparation, with real-time RT-PCR quantification of gene expression performed as above. Preparation of HK cells, primary macrophages and B cells will be described in the next section.

\section{Preparation of HK cells, primary HK macrophages, spleen leucocytes and $\operatorname{IgM}^{+} B$ cells}

Heparinized blood was extracted from freshly killed rainbow trout and $\mathrm{HK}$ and spleen tissue then collected and placed into L-15 medium supplemented with $\mathrm{P} / \mathrm{S}$, 10 units $/ \mathrm{ml}$ heparin and 5\% FCS. Single cell suspensions were generated using $100 \mu \mathrm{m}$ nylon cell strainers (BD Biosciences). The HK cells were then washed and used directly for in vitro stimulation [57] or for preparation of primary macrophages as described previously [59]. To prepare spleen leucocytes, the splenocytes were placed onto $30 \% / 51 \%$ Percoll (GE Healthcare) discontinuous 
density gradients and then centrifuged at $500 \mathrm{~g}$ for 30 min at $4^{\circ} \mathrm{C}$. The interface cells were collected and washed twice with L-15 containing 5\% FCS. The $\operatorname{IgM}^{+}$B cells were purified by FACS sorting of spleen leucocytes using an anti-trout IgM mAb (1.14) [74].

\section{Expression of trout IL-4/13 paralogues during viral infection}

VHSV has been isolated from more than 60 fish species, with rainbow trout the most susceptible [50]. The kidney is one of the major targets of VHSV infection, and thus the expression was examined in the kidney. The pathogenic VHSV strain DK-F1 was used for infection and the challenge performed as described previously [57, 99]. Fish were i.p. injected with $1 \times 10^{8}$ TCID50/fish or the equivalent volume of medium alone as a control. Four fish from each group were killed at 1, 2, 3, 4, 5, 7, 9 and 12 days post-infection and HK tissues collected. Real-time PCR analysis was conducted as described above.

\section{Expression of trout IL-4/13 paralogues during parasitic infection}

T. bryosalmonae infects salmonid fish primarily via the gill epithelia, subsequently gaining access to internal tissues via the vascular system, with the kidney being the main target organ [51]. Trunk kidney tissue collection and cDNA preparation was as described previously [52]. The severity of clinical pathology was analysed and a kidney swelling grade assigned to each fish according to the kidney swelling index system devised by CliftonHadley and colleagues [51]. Real-time PCR analysis was conducted as described above.

\section{Modulation of the expression of trout IL-4/13 paralogues by vaccination and bacterial challenge}

Archived material of a vaccination and challenge experiment against ERM [53] was used. Briefly, a group of 50 trout were vaccinated with AquaVac ${ }^{\mathrm{TM}}$ ERM by i.p. injection of $0.1 \mathrm{ml}$ of vaccine as recommended by the manufacturer (Intervet Schering-Plough). An additional group of 50 trout that were handled in the same way but without vaccination served as controls. The fish were left for 60 days and then challenged by i.p. injection of a pathogenic strain (MT3072) of $Y$. ruckeri $(0.5 \mathrm{ml} / \mathrm{fish}$, $1 \times 10^{6} \mathrm{cfu} / \mathrm{ml}$ ) or $0.5 \mathrm{ml}$ of PBS as control. This dose of MT3072 has been shown to kill $\sim 90 \%$ of fish in previous independent pre-experimental tests, with mortalities occurring from day 3. In this trial four groups of 25 fish were established; the control fish injected with PBS (Naïve/PBS), or Y. ruckeri (Naïve/YR), and vaccinated fish injected with PBS (Vac/PBS) or Y. ruckeri (Vac/YR).
Five fish from each group were killed at 6 h, 24 h, 48 $\mathrm{h}$ and $72 \mathrm{~h}$ after challenge/PBS injection, to assess the responses prior to the expected onset of mortalities in the Naïve/YR group. The head kidney and gills were collected for gene expression analysis as above.

\section{Modulation of the expression of trout IL- 4/13 paralogues in HK cells and primary HK macrophages}

Freshly prepared HK cells (isolated as described above) were stimulated with formalin killed $A$. davidanieli (100 $\mu \mathrm{g} / \mathrm{ml}$, wet weight), $R$. salmoninarum $(100 \mu \mathrm{g} / \mathrm{ml})$, A. salmonicida $(100 \mu \mathrm{g} / \mathrm{ml})$ and $Y$. ruckeri $(100 \mu \mathrm{g} / \mathrm{ml})$; a $\mathrm{T}$ cell mitogen (PHA at $5 \mu \mathrm{g} / \mathrm{ml}$ ), and two recombinant cytokines (rIL-2 at $200 \mathrm{ng} / \mathrm{ml}$ [56] and rIL-21 at $100 \mathrm{ng} /$ ml) [57] for 4 h, 8 h, 24 h, 48 h and 96 h. Four day old primary $\mathrm{HK}$ macrophages [59] were stimulated with PAMPs (poly I:C at $50 \mu \mathrm{g} / \mathrm{ml}$ and peptidoglycan (PGN) at $10 \mu \mathrm{g} / \mathrm{ml}$ ), and recombinant trout cytokines (rIL-1 $\beta$ at $20 \mathrm{ng} / \mathrm{ml}$ [58], rIL-6 at $200 \mathrm{ng} / \mathrm{ml}$ [59], rIFN- $\gamma$ at 20 $\mathrm{ng} / \mathrm{ml}$ [29], and TNF $\alpha$ at $10 \mathrm{ng} / \mathrm{ml}$ [42]) for $4 \mathrm{~h}, 8 \mathrm{~h}$ and $24 \mathrm{~h}$. The concentration chosen for each stimulant was deemed optimal for immune gene expression studies based on our previous work [29, 42, 56-59]. The stimulation was terminated by dissolving the cells in TRI reagent (Sigma, UK). Quantification of gene expression was as described above. Modulated expression was expressed as a fold change calculated as the mean expression levels in stimulated cells normalized to that of time-matched controls.

\section{Cloning, expression and purification of recombinant trout $\mathrm{IL}-4 / 13$ isoforms}

\section{Cloning}

The sequences encoding the mature peptides of trout IL-4/13 isoforms were amplified from cloned cDNA using the primers detailed in Table 3 . The amplified products were cloned to a pET vector (Novagen) as described previously $[57,59]$. Each construct has an ATG codon added at the $\mathrm{N}$-terminus for translation initiation and a sequence encoding for GSGHHHHHHHH added at the $\mathrm{C}$-terminus for purification. Thus, the recombinant trout IL-4/13A, B1 and B2 were 133 aa, 145 aa and 148 aa, with a calculated molecular weight/theoretical $\mathrm{pI}$ of $15.15 \mathrm{kDa} / 7.25,16.51 \mathrm{kDa} / 7.82$ and $16.76 \mathrm{kDa} / 7.75$, respectively.

\section{Expression and purification of trout IL-4/13 isoforms}

For each protein a sequence confirmed plasmid was transformed into BL21 Star (DE3) competent cells (Invitrogen). The induction of recombinant protein production, purification under denaturing conditions, 
Table 3: Primers used for cloning, expression analysis and recombinant protein production of salmonid IL-4/13A and IL-4/13B genes

\begin{tabular}{|c|c|c|c|}
\hline Gene & Primer & Sequences(5'- to 3') & Application \\
\hline \multirow{10}{*}{$\begin{array}{l}\text { Trout } \\
\text { IL-4/13A }\end{array}$} & tIL4aF1 & CCTGCTAGCACCTCAACTTCTCC & 3'-RACE \\
\hline & tIL4aF2 & CCCAACCAAAGATGAAGTCGGTG A & 3'-RACE \\
\hline & tIL4aR1 & GTTGTAAACCCTCAGATGTCGGAC & 5'-RACE \\
\hline & tIL4aR2 & CACCTGGTCTTGGCTCTTCACAAC & 5'-RACE \\
\hline & tIL4aF0 & CGTGTGGTGATGGTGAAGGGAGA & Genomic DNA PCR \\
\hline & tIL4aR3 & CCTTGGTAAAGTCATTTAACGCCAC & Genomic DNA PCR \\
\hline & tIL4aF & ACCACCACAAAGTGCAAGGAGTTCT & Real-time PCR \\
\hline & tIL4aR & CACCTGGTCTTGGCTCTTCACAAC & Real-time PCR \\
\hline & tIL4arF & GCAGCGCACCGGCAGCATAG & Recombinant protein \\
\hline & tIL4arR & TGGTTTGGAGTTGATTTTTTGG & Recombinant protein \\
\hline \multirow{2}{*}{$\begin{array}{l}\text { Salmon } \\
\text { IL-4/13B1 }\end{array}$} & sIL4b1F1 & TCTGCATAGCGGAGAAGATTCTGTC & 3'-RACE \\
\hline & sIL4b1F2 & CGAAGAGCAGTACGGGACTTCAG & 3'-RACE \\
\hline \multirow{6}{*}{$\begin{array}{l}\text { Trout } \\
\text { IL-4/13B1 }\end{array}$} & tIL4b1F1 & TTGAACCTTCTTCACCCCGAG & PCR cloning \\
\hline & tIL4b1R1 & ATTGGACTATGCACGATCGACAG & PCR cloning \\
\hline & tIL4b1F & GAGATTCATCTACTGCAGAGGATCATGA & Real-time PCR \\
\hline & tIL4b1R & GCAGTTGGAAGGGTGAAGCTTATTGTA & Real-time PCR \\
\hline & tIL4b1rF & GCGCCCACTAAGACACCTGA & Recombinant protein \\
\hline & tIL4b1rR & AAGTGCTGGGGTCGTTTTGTG & Recombinant protein \\
\hline \multirow{2}{*}{$\begin{array}{l}\text { Salmon } \\
\text { IL-4/13B2 }\end{array}$} & sIL4b2F1 & TTGAACCTTCTTCACCCCGAG & 3'-RACE \\
\hline & sIL4b2F2 & ACCTTCTTCACCCCGAGGG & 3'-RACE \\
\hline \multirow{6}{*}{$\begin{array}{l}\text { Trout } \\
\text { IL-4/13B2 }\end{array}$} & tIL4b2F1 & АССТTCTTCACССCGAGGG & PCR cloning \\
\hline & tIL4b2R1 & TCGACAGCGTTTCCATCAGTCC & PCR cloning \\
\hline & tIL4b2F & GAGACTCATCTATTGCGTATGATCATCG & Real-time PCR \\
\hline & tIL4b2R & TGCAGTTGGTTGGATGAAACTTATTGTA & Real-time PCR \\
\hline & tIL4b2rF & GCGCCCACTAAGACATCTGA & Recombinant protein \\
\hline & tIL4b2rR & GCAAAGCTCTAGGGTTGTTTGTG & Recombinant protein \\
\hline
\end{tabular}

refolding, re-purification under native conditions, SDS-PAGE analysis of proteins and quantification of protein concentration were as described previously $[57,59,100]$. The refolding buffer contained $25 \mathrm{mM}$ MES (MW), pH6.5 (6.5), 25\% glycerol, $0.6 \mathrm{M}$ arginine monohydrochloride, $0.5 \%$ Triton- $100,0.2 \%$ PEG3350, 10 $\mathrm{mM}$ 2-mercaptoethanol and $1 \mathrm{mM}$ EDTA. The purified proteins were desalted in desalting buffer (DSB) (50 $\mathrm{mM}$ Hepes, pH7.0, $140 \mathrm{mM} \mathrm{NaCl}, 10 \mathrm{mM}$ arginine, $50 \%$ glycerol and $5 \mathrm{mM}$ 2-ME) using PD-10 Desalting Columns (GE Healthcare). After sterilization with a 0.2 $\mu \mathrm{m}$ filter, the recombinant proteins were aliquoted and stored at $-80^{\circ} \mathrm{C}$ ready for stimulation of cells.
Modulation of gene expression in HK cells by recombinant trout IL-4/13 isoforms

The recombinant proteins produced above were initially added to HK cells and splenocytes $\left(2 \times 10^{6}\right.$ cells/ $\mathrm{ml})$ at $200 \mathrm{ng} / \mathrm{ml}$ for different times $(4 \mathrm{~h}$ to $24 \mathrm{~h})$ to test their bioactivity in terms of modulating gene expression as described previously $[42,101]$. Further tests were conducted using HK cells with different doses ( $0.01 \mathrm{ng}$ to $1,000 \mathrm{ng} / \mathrm{ml}$ ) for $4 \mathrm{~h}$, or $200 \mathrm{ng} / \mathrm{ml}$ of recombinant proteins for different times ( $2 \mathrm{~h}$ to $96 \mathrm{~h}$ ). The experiments were terminated by dissolving the cells in TRI reagent and realtime PCR analysis was conducted as described above. After an initial screening of over 200 genes, the expression of 62 trout immune genes, including those encoding for cellular markers, cytokines and cytokine receptors, were analysed in the time course experiment using primers detailed in Table S2. 


\section{The Enzyme-Linked ImmunoSpot (ELISPOT) assay}

ELISPOT was used to quantify the number of IgMsecreting B cells. ELISPOT plates containing Inmobilon-P membranes (Millipore) were activated with $70 \%$ ethanol for $30 \mathrm{~s}$, coated with anti-trout IgM mAb (clone $4 \mathrm{C} 10$ ) at 2 $\mu \mathrm{g} / \mathrm{ml}$, diluted in PBS and incubated overnight at $4^{\circ} \mathrm{C}$. To block non-specific binding to the membrane, plates were then incubated with PBS containing $2 \%$ bovine serum albumin (BSA) for $2 \mathrm{~h}$ at room temperature. Stimulated (with rIL-4/13A, rIL-4/13B2, LPS, or LPS in combination with rIL-4/13A or rIL-4/13B2) or unstimulated splenocytes from individual fish were added to the wells in triplicate at a concentration of $1 \times 10^{5}$ cells per well. After $72 \mathrm{~h}$ of incubation at $20^{\circ} \mathrm{C}$, cells were washed away 5 times with PBS and plates were blocked again with $2 \%$ BSA in PBS for $1 \mathrm{~h}$ at room temperature. After blocking, biotinylated anti-trout IgM mAb (clone 4C10) was added to the plates and incubated at $1 \mu \mathrm{g} / \mathrm{ml}$ for $1 \mathrm{~h}$ at room temperature. Following additional washing steps (5 times in PBS) the plates were developed using streptavidin-HRP (Thermo Scientific) for $1 \mathrm{~h}$ at room temperature, washed again with PBS and incubated with 3-amino 9-ethylcarbazole (Sigma Aldrich) for $30 \mathrm{~min}$ at room temperature in the dark. Substrate reaction was stopped by washing the plates with tap water. Once the membranes had dried, they were digitally scanned and spot counts determined by the ImmunoSpot Series 45 Micro ELISPOT Analyzer.

\section{Cell proliferation assay}

A BrdU Flow Kit (Becton Dickinson) was used to measure the specific proliferation of $\operatorname{IgM}^{+}$cells following the manufacturer's instructions. Splenocytes at a concentration of $2 \times 10^{6}$ cells $/ \mathrm{ml}$ were incubated for 3 days at $20^{\circ} \mathrm{C}$ with different stimuli (rIL-4/13A, rIL$4 / 13 \mathrm{~B} 2$ or LPS as a positive control). Bromodeoxyuridine (BrdU, $10 \mu \mathrm{M}$ ) was then added to the cultures and cells were incubated for an additional $24 \mathrm{~h}$. Afterwards the cells were collected and stained with a phycoerythrin (PE) conjugated anti-trout IgM mAb (1.14), then fixed and permeabilized with Cytofix/Cytoperm Buffer for 15 min on ice. Next the cells were incubated with Cytoperm Permeabilization Buffer Plus for $10 \mathrm{~min}$ on ice and refixed with Cytofix/Cytoperm Buffer for $5 \mathrm{~min}$ at room temperature. Cells were then incubated with DNase (30 $\mu \mathrm{g} / 10^{6}$ cells) for $1 \mathrm{~h}$ at $37^{\circ} \mathrm{C}$, to expose the incorporated BrdU. Finally, they were stained with a FITC conjugated anti-BrdU antibody for $20 \mathrm{~min}$ at room temperature and analysed by flow cytometry (BD FACSCalibur, BD Biosciences).

\section{Cell sorting}

Splenocytes from individual fish were dispensed into 24-well plates at a density of $1 \times 10^{6}$ cells $/ \mathrm{ml}$ and incubated with rIL-4/13A, rIL-4/13B2 or LPS as a reference. Non-stimulated controls were also included. Cells were then incubated at $20^{\circ} \mathrm{C}$ for $24 \mathrm{~h}$. The leucocytes were then collected from the wells by gentle scrapping, resuspended in PBS and incubated for $30 \mathrm{~min}$ on ice with a PE conjugated anti-trout IgM mAb (1.14) [74]. Following two washing steps, cells were resuspended in PBS and $\mathrm{IgM}^{+}$cells were isolated by FACS sorting in a BD FACSAria III (BD Biosciences), using first their FSC/ SSC profiles (to exclude the granulocyte gate) and then on the basis of the fluorescence emitted by the anti-trout IgM $\mathrm{mAb}$ [102]. $\mathrm{IgM}^{+}$and $\mathrm{IgM}^{-}$cells were then collected in different tubes for RNA isolation. Expression of IgM and the absence of T cell markers (CD3 and TCR) was verified by PCR in selected samples to confirm effective sorting.

\section{Statistical analysis}

The data were statistically analyzed using the SPSS Statistics package 22 (SPSS Inc., Chicago, Illinois). The analysis of real-time PCR data was as described previously $[29,57]$. One way-analysis of variance (ANOVA) and the LSD post hoc test were used to analyse expression data derived from the infection studies, with $p<0.05$ between treatment and control groups considered significant. For the tissue distribution of expression and in vitro experiments that consisted of sample sets from individual fish, a Paired-Samples T-test was applied.

\section{Abbreviations}

AMP, antimicrobial peptide; APP, acute phase protein; CDS, coding sequence; ERM, enteric redmouth disease; EST, expressed sequence tag; HK, head kidney; Ig, immunoglobulin; IL, interleukin; ILC2, type-2 innate lymphoid cells; i.p., intraperitoneal; PAMPs, pathogenassociated molecular patterns; PGN, peptidoglycan; PHA, phytohaemagglutinin; PKD, proliferative kidney disease; Poly IC, polyinosinic-polycytidylic acid; RACE, rapid amplification of cDNA ends; STAT, signal transducer and activator of transcription; Th, T-helper; UTR, untranslated region; VHSV, viral haemorrhagic septicaemia virus; WGD, whole genome duplication; WGS, whole genome shotgun sequence; $\gamma \mathrm{C}$, common- $\gamma$ chain.

\section{ACKNOWLEDGMENTS}

The VHSV-infected samples were generated within the Scottish Government funded research project FC1996 and kindly provided by Marine Scotland staff. Thanks to 
ELANCO for providing the $A$. davidanieli (Renogen).

\section{FINANCIAL SUPPORT}

T. W. received funding from the MASTS pooling initiative (The Marine Alliance for Science and Technology for Scotland). MASTS is funded by the Scottish Funding Council (grant reference HR09011) and contributing institutions. Y.J., W.H. and Q.X. were supported financially by the National Scholarship Council of China. Z.Q. was supported by grants from the National Natural Science Foundation of China (31302221) and the overseas training plan for young and middle-aged teachers and principals of colleges and universities in Jiangsu Province, China. M.M.C. was funded by an Ángeles Alvariño postdoctoral contract from the Consejo Superior de Investigaciones Científicas and the Xunta de Galicia. P.D.-R. was funded by a European Commission (EC) Marie Curie Intra European Fellowship (FP7). J.W.H. was funded by the Biotechnology and Biological Sciences Research Council (BB/K009125/1). This work was also supported financially by the EC, under contract Nos. 222719 (LIFECYCLE) and 311993 (TargetFish), and by the European Research Council Starting Grant 2011 (contract No. 280469).

\section{CONFLICTS OF INTEREST}

All authors declare no financial or commercial conflict of interest.

\section{REFERENCES}

1. McCormick, S. Heller, NM. Commentary: IL-4 and IL-13 receptors and signaling. Cytokine. 2015; 75:38-50.

2. Paul WE. History of interleukin 4. Cytokine. 2015; 75:3-7.

3. Howard M, Farrar J, Hilfiker M, Johnson B, Takatsu K, Hamaoka T, Paul WE. Identification of a T cell-derived B cell growth factor distinct from interleukin 2. J Exp Med. 1982; 155:914-23.

4. Isakson PC, Puré E, Vitetta ES, Krammer PH. T cellderived $\mathrm{B}$ cell differentiation factor(s). Effect on the isotype switch of murine B cells. J Exp Med. 1982; 155:734-748.

5. Coffman RL, Ohara J, Bond MW, Carty J, Zlotnik A, Paul WE. B cell stimulatory factor- 1 enhances the $\operatorname{IgE}$ response of lipopolysaccharide-activated B cells. J Immunol. 1986; 136:4538-4541.

6. Mosmann TR, Bond MW, Coffman RL, Ohara J, Paul WE. T-cell and mast cell lines respond to B-cell stimulatory factor 1. Proc Natl Acad Sci U S A. 1986; 83:5654-5658.

7. Lowenthal JW, Castle BE, Christiansen J, Schreurs J, Rennick D, Arai N, et al. Expression of high affinity receptors for murine interleukin 4 (BSF-1) on hemopoietic and nonhemopoietic cells. J Immunol. 1988; 140:456-464.
8. Brown KD, Zurawski SM, Mosmann TR, Zurawski G. A family of small inducible proteins secreted by leukocytes are members of a new superfamily that includes leukocyte and fibroblast-derived inflammatory agents, growth factors, and indicators of various activation processes. J Immunol. 1989; 142:679-687.

9. Redpath SA, Heieis G, Perona-Wright G. Spatial regulation of IL-4 signaling in vivo. Cytokine. 2015; 75:51-56.

10. Wang T, Secombes CJ. Evolution of IL-4 and IL-13 and their receptors, Cytokine. 2015; 75:8-13.

11. Gadani SP, Cronk JC, Norris GT, Kipnis J. IL-4 in the brain: a cytokine to remember. J Immunol. 2012; 189:42134219.

12. Zhu J. T helper 2 (Th2) cell differentiation, type 2 innate lymphoid cell (ILC2) development, and regulation of interleukin-4 (IL-4) and IL-13 production. Cytokine. 2015; 75:14-24.

13. Bao K, Reinhardt RL. The differential expression of IL-4 and IL-13 and its impact on type-2 immunity. Cytokine. $2015 ; 75: 25-37$.

14. Gour N, Wills-Karp M. IL-4 and IL-13 signaling allergic airway disease. Cytokine. 2015; 75:68-78.

15. Suzuki A, Leland P, Joshi BH, Puri RK. Targeting of IL-4 and IL-13 receptors for cancer therapy. Cytokine. 2015; $75: 79-88$.

16. Kaplan MH, Schindler U, Smiley ST, Grusby MJ. Stat6 is required for mediating responses to IL-4 and for development of Th2 cells. Immunity. 1996; 4:313-9.

17. Zhu J, Cote-Sierra J, Guo L, Paul WE. Stat5 activation plays a critical role in Th2 differentiation. Immunity. 2003; 19:739-48.

18. McLeod JJA, Baker BN, Ryan JJ. Mast cell production and response to IL-4 and IL-13. Cytokine. 2015; 75:57-61.

19. Shea-Donohue T, Sun R, Bohl JA, McLean LP, Zhao A. Enteric nematodes and the path to up-regulation of type 2 cytokines IL-4 and IL-13. Cytokine. 2015; 75:62-67.

20. Gessner A, Mohrs K, Mohrs M. Mast cells, basophils, and eosinophils acquire constitutive IL-4 and IL-13 transcripts during lineage differentiation that are sufficient for rapid cytokine production. J Immunol. 2005; 174:1063-1072.

21. Gibbs BF, Haas H, Falcone FH, Albrecht C, Vollrath IB, Noll T, et al. Purified human peripheral blood basophils release interleukin-13 and preformed interleukin-4 following immunological activation. Eur J Immunol. 1996; 26:2493-2498.

22. Buechel HM, Stradner MH, D'Cruz LM. Stages versus subsets: Invariant Natural Killer $\mathrm{T}$ cell lineage differentiation. Cytokine. 2015; 2:204-209.

23. Artis D, Spits H. The biology of innate lymphoid cells. Nature. 2015; 517:293-301.

24. Lupardus PJ, Birnbaum ME, Garcia KC. Molecular basis for shared cytokine recognition revealed in the structure of an unusually high affinity complex between IL-13 and IL13Ralpha2. Structure. 2010; 18:332-342. 
25. van der Velden VH, Naber BA, Wierenga-Wolf AF, Debets $\mathrm{R}$, Savelkoul HF, Overbeek SE, et al. Interleukin 4 receptors on human bronchial epithelial cells. An in vivo and in vitro analysis of expression and function. Cytokine. 1998; 10:803-813.

26. Allen JE, Wynn TA. Evolution of Th2 immunity: a rapid repair response to tissue destructive pathogens. PLoS Pathog. 2011; 7:e1002003.

27. Wang T, Secombes CJ. Cloning and expression of a putative common cytokine receptor gamma chain $(\gamma \mathrm{C})$ gene in rainbow trout (Oncorhynchus mykiss). Fish Shellfish Immunol. 2001,11:233-244.

28. Wang T, Huang W, Costa MM, Secombes CJ. The gammachain cytokine/receptor system in fish: more ligands and receptors. Fish Shellfish Immunol. 2011; 31:673-687.

29. Wang T, Huang W, Costa MM, Martin SAM, Secombes CJ. Two copies of the genes encoding the subunits of putative interleukin (IL)-4/IL-13 receptors, IL-4Ra, IL13Ra1 and IL-13Ra2, have been identified in rainbow trout (Oncorhynchus mykiss) and have complex patterns of expression and modulation. Immunogenetics. 2011; 63:235253.

30. Li JH, Shao JZ, Xiang LX, Wen Y. Cloning, characterization and expression analysis of pufferfish IL-4 cDNA: the first evidence of Th2-type cytokine in fish. Mol Immunol 2007; 44:2078-86.

31. Bird S, Secombes CJ. Danio rerio partial mRNA for interleukin-4. GenBank Accession No. AM403245; 2006.

32. Ohtani M, Hayashi N, Hashimoto K, Nakanishi T, Dijkstra JM. Comprehensive clarification of two paralogous interleukin 4/13 loci in teleost fish. Immunogenetics. 2008; 60:383-397.

33. Dijkstra JM. T(H)2 and T-reg candidate genes in elephant shark. Nature. 2014; 511:E7-E10

34. Secombes CJ, Zou J, Bird S. Cytokines of cartilaginous fish. In: Smith SL, Sim RB, Flajnik MF, editors. Immunobiology of the shark, 2015; CRC Press; p123-42.

35. Takizawa F, Koppang EO, Ohtani M, Nakanishi T, Hashimoto K, Fischer U, et al. Constitutive high expression of interleukin-4/13A and GATA-3 in gill and skin of salmonid fishes suggests that these tissues form Th2-skewed immune environments. Mol Immunol. 2011; 48:1360-1368.

36. Chettri JK, Kuhn JA, Jaafar RM, Kania PW, Moller OS, Buchmann K. Epidermal response of rainbow trout to Ichthyobodo necator: Immunohistochemical and gene expression studies indicates a Th1-/Th2-like switch. J Fish Disease. 2014; 37:771-783.

37. Yamaguchi T, Katakura F, Someya K, Dijkstra JM, Moritono T, Nakanishi T. Clonal growth of carp (Cyprinus carpio) $\mathrm{T}$ cells in vitro: long-term proliferation of Th2-like cells. Fish Shellfish Immunol. 2013; 34:433-442.

38. Lin AF, Xiang LX, Wang QL, Dong WR, Gong YF, Shao JZ. The DCSIGN of zebrafish: insights into the existence of a CD209 homologue in a lower vertebrate and its involvement in adaptive immunity. J Immunol. 2009; 183:7398-7410.

39. Zhu L-y, Pan P-p, Fang W, Shao J-z, Xiang L-x. Essential role of IL-4 and IL-4Ra in interaction in adaptive immunity of zebrafish: insight into the origin of Th2-like regulatory mechanisms in ancient vertebrates. J Immunol. 2012; 188:5571-5584.

40. Macqueen DJ, Johnston IA. A well-constrained estimate for the timing of the salmonid whole genome duplication reveals major decoupling from species diversification. Proc Roy Soc B. 2014; 281:20132881.

41. Husain M, Bird S, van Zwieten R, Secombes CJ, Wang T. Cloning of the IL-1 $\beta 3$ gene and IL-1 $1 \beta 4$ pseudogene in salmonids uncovers a second type of IL-1 $\beta$ gene in teleost fish. Dev Comp Immunol. 2012; 38:431-46.

42. Hong S, Li R, Xu Q, Secombes CJ, Wang T. Two types of TNF- $\alpha$ exist in teleost fish: Phylogenetic, expressional and bioactivity analysis of Type II TNF-a3 in rainbow trout Oncorhynchus mykiss. J Immunol. 2013; 191:59595972.

43. Wang T, Husain M. The expanding repertoire of the IL12 cytokine family in teleost fish: Identification of three paralogues each of the p35 and p40 genes in salmonids, and comparative analysis of their expression and modulation in Atlantic salmon Salmo salar. Dev Comp Immunol. 2014; 46:194-207.

44. Tamura K, Stecher G, Peterson D, Filipski A, Kumar S. MEGA6: molecular evolutionary genetics analysis version 6.0. Mol Biol Evol. 2013; 30:2725-2729.

45. LaPorte SL, Juo ZS, Vaclavikova J, Colf LA, Qi X, Heller NM, Keegan AD, Garcia KC. Molecular and structural basis of cytokine receptor pleiotropy in the interleukin-4/13 system. Cell. 2008; 132:259-272.

46. Mueller TD, Zhang JL, Sebald W, Duschl A. Structure, binding, and antagonists in the IL-4/IL-13 receptor system. Biochimica et Biophysica Acta. 2002; 1592:237-250.

47. Le HV, Seelig GF, Syto R, Ramanathan L, Windsor WT, Borkowski D, Trotta PP. Selective proteolytic cleavage of recombinant human interleukin 4. Evidence for a critical role of the C-terminus. Biochemistry. 1991; 30:9576-9582.

48. Tsarbopoulos A, Varnerin J, Cannon-Carlson S, Wylie D, Pramanik B, Tang J, Nagabhushan TL. Mass spectrometric mapping of disulfide bonds in recombinant human interleukin-13. J Mass Spectrom. 2000; 35:446-453.

49. Ceroni A, Passerini A, Vullo A, Frasconi P. DISULFIND: a disulfide bonding state and cysteine connectivity prediction server. Nucleic Acids Res. 2006; 34 (Web Server issue):W177-81.

50. Skall HF, Olesen NJ, Mellergaard S. Viral haemorrhagic septicaemia virus in marine fish and its implications for fish farming--a review. J Fish Dis. 2005; 28:509-529.

51. Clifton-Hadley RS, Bucke D, Richards RH. A study of the sequential clinical and pathological changes during proliferative kidney disease in rainbow trout, Salmo 
gairdneri Richardson. J Fish Dis. 1987; 10:335-352.

52. Gorgoglione B, Wang T, Secombes CJ, Holland JW. Immune gene expression profiling of Proliferative Kidney Disease in rainbow troutOncorhynchus mykiss reveals a dominance of anti-inflammatory, antibody and $\mathrm{T}$ helper cell-like activities. Vet Res. 2013; 44:55.

53. Harun NO, Wang T, Secombes CJ. Gene expression profiling in naïve and vaccinated rainbow trout after Yersinia ruckeri infection: insights into the mechanisms of protection seen in vaccinated fish. Vaccine. 2011; 29:4388-4399.

54. Wang T, Jiang Y, Wang A, Husain M, Xu Q, Secombes CJ. Identification of the salmonid IL-17A/F1a/b, IL-17A/ F2b, IL-17A/F3 and IL-17N genes and analysis of their expression following in vitro stimulation and infection. Immunogenetics. 2015; 67:395-412.

55. Salonius K, Siderakis C, MacKinnon AM, Griffiths SG. Use of Arthrobacter davidanieli as a live vaccine against Renibacterium salmoninarum and Piscirickettsia salmonis in salmonids. Dev Biol (Basel). 2005; 121:189197.

56. Díaz-Rosales P, Bird S, Wang TH, Fujiki K, Davidson WS, Zou J, Secombes CJ. Rainbow trout interleukin-2: cloning, expression and bioactivity analysis. Fish Shellfish Immunol. 2009; 27:414-22.

57. Wang T, Diaz-Rosales P, Costa MM, Campbell S, Snow M, Collet B, Martin SA, Secombes CJ. Functional characterization of a nonmammalian IL-21: rainbow trout Oncorhynchus mykiss IL-21 upregulates the expression of the Th cell signature cytokines IFN-gamma, IL-10, and IL-22. J Immunol. 2011; 186:708-821.

58. Hong S, Zou J, Crampe M, Peddie S, Scapigliati G, Bols $\mathrm{N}$, Cunningham C, Secombes CJ. The production and bioactivity of rainbow trout (Oncorhynchus mykiss) recombinant IL-1 beta. Vet Immunol Immunopathol. 2001; 81:1-14.

59. Costa MM, Maehr T, Diaz-Rosales P, Secombes CJ, Wang T. Bioactivity studies of rainbow trout (Oncorhynchus mykiss) interleukin-6: effects on macrophage growth and antimicrobial peptide gene expression. Mol Immunol. 2011; 48:1903-1916.

60. Gasteiger E, Hoogland C, Gattiker A, Duvaud S, Wilkins M R, Appel RD, Bairoch A. Protein Identification and Analysis Tools on the ExPASy Server. In: Walker JM (ed) The Proteomics Protocols Handbook. 2005; Humana Press, pp. 571-607.

61. Gao Q, Nie P, Thompson KD, Adams A, Wang T, Secombes CJ, Zou J. The search for the IFN-gamma receptor in fish: Functional and expression analysis of putative binding and signalling chains in rainbow trout Oncorhynchus mykiss. Dev Comp Immunol. 2009; 33:920-931.

62. Costa MM, Wang T, Monte MM, Secombes CJ. Molecular characterization and expression analysis of the putative interleukin 6 receptor (IL-6R $\alpha$ and glycoprotein-130) in rainbow trout (Oncorhynchus mykiss): salmonid IL$6 \mathrm{R} \alpha$ possesses a polymorphic N-terminal Ig domain with variable numbers of two repeats. Immunogenetics. 2012; 64:229-44.

63. Wang T, Holland JW, Martin SA, Secombes CJ. Sequence and expression analysis of two $\mathrm{T}$ helper master transcription factors, T-bet and GATA3, in rainbow trout Oncorhynchus mykiss and analysis of their expression during bacterial and parasitic infection. Fish Shellfish Immunol. 2010; 29:705715.

64. Wang T, Monte MM, Huang W, Boudinot P, Martin SA, Secombes CJ. Identification of two FoxP3 genes in rainbow trout (Oncorhynchus mykiss) with differential induction patterns. Mol Immunol. 2010; 47:2563-2574.

65. Monte MM, Wang T, Costa MM, Harun NO, Secombes CJ. Cloning and expression analysis of two ROR- $\gamma$ homologues (ROR- $\gamma \mathrm{a} 1$ and ROR- $\gamma \mathrm{a} 2)$ in rainbow trout Oncorhynchus mykiss. Fish Shellfish Immunol. 2012; 33:365-374.

66. Ohta Y, Landis E, Boulay T, Phillips RB, Collet B, Secombes CJ, Flajnik MF, Hansen JD. Homologs of CD83 from elasmobranch and teleost fish. J Immunol. 2004; 173:4553-4560.

67. Johansson P, Wang T, Collet B, Corripio-Miyar Y, Monte MM, Secombes CJ, Zou J. Identification and expression modulation of a C-type lectin domain family 4 homologue that is highly expressed in monocytes/macrophages in rainbow trout (Oncorhynchus mykiss). Dev Comp Immunol. 2015; 54:55-65.

68. Johansson P, Corripio-Miyar Y, Wang T, Collet B, Secombes CJ, Zou J. Characterisation and expression analysis of the rainbow trout (Oncorhynchus mykiss) homologue of the human dendritic cell marker CD208/ lysosomal associated membrane protein 3. Dev Comp Immunol. 2012; 37:402-413.

69. Zhang YA, Hikima J, Li J, LaPatra SE, Luo YP, Sunyer JO. Conservation of structural and functional features in a primordial $\mathrm{CD} 80 / 86$ molecule from rainbow trout (Oncorhynchus mykiss), a primitive teleost fish. J Immunol. 2009; 183:83-96.

70. Kokkinos PA, Kazantzi A, Sfyroera G, Zarkadis IK. Molecular cloning of leukocyte cell-derived chemotaxin 2 in rainbow trout. Fish Shellfish Immunol. 2005; 18:371380 .

71. Hwang HJ, Jung TW, Hong HC, Seo JA, Kim SG, Kim NH, Choi KM, Choi DS, Baik SH, Yoo HJ. LECT2 induces atherosclerotic inflammatory reaction via CD209 receptormediated JNK phosphorylation in human endothelial cells. Metabolism. 2015; doi: 10.1016/j.metabol.2015.06.001.

72. Harun NO, Costa MM, Secombes CJ, Wang $T$. Sequencing of a second interleukin-10 gene in rainbow trout Oncorhynchus mykiss and comparative investigation of the expression and modulation of the paralogues in vitro and in vivo. Fish Shellfish Immunol. 2011; 31:107117. 
73. Wang $T$, Secombes CJ. Rainbow trout suppressor of cytokine signalling (SOCS)-1, 2 and 3: molecular identification, expression and modulation. Mol Immunol. $2008 ; 45: 1449-1457$

74. DeLuca D, Wilson M, Warr GW. Lymphocyte heterogeneity in the trout, Salmo gairdneri, defined with monoclonal antibodies to IgM. Eur J Immunol. 1983; 13:546-551.

75. Maehr T, Vecino JL, Wadsworth S, Wang T, Secombes CJ. Four CISH paralogues are present in rainbow trout Oncorhynchus mykiss: differential expression and modulation during immune responses and development. Mol Immunol. 2014; 62:186-98.

76. Bhattacharjee A, Shukla M, Yakubenko VP, Mulya A, Kundu S, Cathcart MK. IL-4 and IL-13 employ discrete signaling pathways for target gene expression in alternatively activated monocytes/macrophages. Free Radic Biol Med. 2013; 54:1-16.

77. Wang $\mathrm{T}$, Kono $\mathrm{T}$, Monte MM, Kuse H, Costa MM, Korenaga H, Maehr T, Husain M, Sakai M, Secombes CJ. Identification of IL-34 in teleost fish: differential expression of rainbow trout IL-34, MCSF1 and MCSF2, ligands of the MCSF receptor. Mol Immunol. 2013; 53:398-409.

77. Wang T, Hanington PC, Belosevic M, Secombes CJ. Two macrophage colony-stimulating factor genes exist in fish that differ in gene organization and are differentially expressed. J Immunol. 2008; 181:3310-3322.

79. Severinson E. Identification of the IgG1 induction factor (interleukin 4). Front Immunol. 2014; 5:628.

80. Zhang YA, Salinas I, Li J, Parra D, Bjork S, Xu Z, LaPatra SE, Bartholomew J, Sunyer JO. IgT, a primitive immunoglobulin class specialized in mucosal immunity. Nat Immunol. 2010; 11:827-35.

81. Motomura Y, Morita H, Moro K, Nakae S, Artis D, Endo TA, Kuroki Y, Ohara O,Koyasu S, Kubo M. Basophilderived interleukin-4 controls the function of natural helper cells, a member of ILC2s, in lung inflammation. Immunity. 2014; 40:758-771.

82. Licona-Limón P, Kyun im L, Palm NW, Flavell RA. TH2, allergy and group 2 innate lymphoid cells. Nature Immunol. 2013; 14:536-542.

83. Fukuoka et al. Identification of a novel type 2 innate immunocyte with the ability to enhance IgE production. Int Immunol. 2013; 25:373-382.

84. Serafini N, Di Santo JP. Effector cells of the mucosal immune system: innate lymphoid cells. In: Mucosal Immunology. Edited by J. Mestecky, W. Strober, M. Russell, H. Cheroutre, B. N. Lambrecht, B. Kelsall, Elsevier. 2015.

85. Moro K1, Yamada T, Tanabe M, Takeuchi T, Ikawa T, Kawamoto H, Furusawa J, Ohtani M, Fujii H, Koyasu S. Innate production of $\mathrm{T}(\mathrm{H}) 2$ cytokines by adipose tissueassociated c-Kit(+)Sca-1(+) lymphoid cells. Nature. 2010; 463:540-544.
86. Pulendran B, Artis D. New paradigms in type 2 immunity. Science. 2012; 337:431-435.

87. Wang $\mathrm{T}$, Secombes CJ. Complete sequencing and expression of three complement components, C1r, C4 and $\mathrm{C} 1$ inhibitor, of the classical activation pathway of the complement system in rainbow trout Oncorhynchus mykiss. Immunogenetics. 2003; 55:615-628.

88. Altschul SF, Gish W, Miller W, Myers EW, Lipman DJ. Basic Local Alignment Search Tool. J. Mol. Biol. 1990; 215:403-410.

89. Berthelot C, Brunet F, Chalopin D, Juanchich A, Bernard $\mathrm{M}$, Noel B, et al. The rainbow trout genome provides novel insights into evolution after whole-genome duplication in vertebrates. Nature Communications. 2014; 5:3657.

90. Petersen TN, Brunak S, von Heijne G, Nielsen H. SignalP 4.0: discriminating signal peptides from transmembrane regions. Nature Methods. 2011; 8:785-786.

91. Campanella JJ, Bitincka L, Smalley J. MatGAT: An application that generates similarity/identity matrices using protein or DNA sequences. BMC Bioinformatics 2003; 4:29.

92. Chenna R, Sugawara H, Koike T, Lopez R, Gibson TJ, Higgins DG, et al. Multiple sequence alignment with the clustal series of programs. Nucleic Acids Res. 2003; 31:3497-3500.

93. Louis A, Muffato M, Roest Crollius H. Genomicus: five genome browsers for comparative genomics in eukaryota. Nucleic Acids Res. 2013; 41: D700-705.

94. Jiang Y, Husain M, Qi Z, Bird S, Wang T. Identification and expression analysis of two interleukin-23 $\alpha$ (p19) isoforms, in rainbow troutOncorhynchus mykiss and Atlantic salmon Salmo salar. Mol Immunol. 2015; 66:216-628.

95. Ganassin RC, Bols NC. Development of a monocyte/ macrophage-like cell line, RTS11, from rainbow trout spleen. Fish Shellfish Immunol. 1998; 8:457-476,

96. Lee LE, Clemons JH, Bechtel DG, Caldwell SJ, Han KB, Pasitschniak-Arts $M$, et al. Development and characterization of a rainbow trout liver cell line expressing cytochrome P450-dependent monooxygenase activity. Cell Biol Toxicol. 1993; 9:279-294.

97. Wolf K, Quimby MC. Established eurythermic lines of fish cells in vitro. Science. 1962; 135:1065.

98. Schirmer K, Chan AG, Greenberg BM, Dixon DG, Bols NC. Ability of 16 priority PAHs to be photocytotoxic to a cell line from the rainbow trout gill. Toxicology. 1998; 127:143-155.

99. Campbell S, Collet B, Einer-Jensen K, Secombes CJ, Snow M. Identifying potential virulence determinants in viral haemorrhagic septicaemia virus (VHSV) for rainbow trout. Dis Aquat Organ. 2009; 86:205-212.

100. Wangkahart E, Scott C, Secombes CJ, Wang T. Reexamination of the rainbow trout (Oncorhynchus mykiss) immune response to flagellin:Yersinia ruckeri flagellin is a potent activator of acute phase proteins, anti-microbial 
peptides and pro-inflammatory cytokines in vitro. Dev Comp Immunol. 2016; 57:75-87.

101. Wang T, Husain M, Hong S, Holland JW. Differential expression, modulation and bioactivity of distinct fish IL12 isoforms: implication towards the evolution of Th1-like immune responses. Eur J Immunol. 2014; 44:1541-1551.

102. Abós B, Castro R, Pignatelli J, Luque A, González L, Tafalla C. Transcriptional heterogeneity of IgM+ cells in rainbow trout (Oncorhynchus mykiss) tissues. PLoS One. 2013; 8:e82737. 